\title{
Influence of dynamic vegetation on climate change and terrestrial carbon storage in the Last Glacial Maximum
}

\author{
R. O'ishi ${ }^{1,2}$ and A. Abe-Ouchi ${ }^{1,3}$ \\ ${ }^{1}$ Atmosphere and Ocean Research Institute, University of Tokyo, Kashiwa, Japan \\ ${ }^{2}$ National Institute of Polar Research, Tokyo, Japan \\ ${ }^{3}$ Frontier Research Center for Global Change, Yokohama, Japan \\ Correspondence to: R. O’ishi (ryo@aori.u-tokyo.ac.jp) \\ Received: 5 November 2012 - Published in Clim. Past Discuss.: 27 November 2012 \\ Revised: 10 May 2013 - Accepted: 3 June 2013 - Published: 22 July 2013
}

\begin{abstract}
When the climate is reconstructed from paleoevidence, it shows that the Last Glacial Maximum (LGM, ca. $21000 \mathrm{yr}$ ago) is cold and dry compared to the present-day. Reconstruction also shows that compared to today, the vegetation of the LGM is less active and the distribution of vegetation was drastically different, due to cold temperature, dryness, and a lower level of atmospheric $\mathrm{CO}_{2}$ concentration (185 ppm compared to a preindustrial level of $285 \mathrm{ppm}$ ). In the present paper, we investigate the influence of vegetation change on the climate of the LGM by using a coupled atmosphere-ocean-vegetation general circulation model (AOVGCM, the MIROC-LPJ). The MIROC-LPJ is different from earlier studies in the introduction of a bias correction method in individual running GCM experiments. We examined four GCM experiments (LGM and preindustrial, with and without vegetation feedback) and quantified the strength of the vegetation feedback during the LGM. The result shows that global-averaged cooling during the LGM is amplified by $+13.5 \%$ due to the introduction of vegetation feedback. This is mainly caused by the increase of land surface albedo due to the expansion of tundra in northern high latitudes and the desertification in northern middle latitudes around $30^{\circ} \mathrm{N}$ to $60^{\circ} \mathrm{N}$. We also investigated how this change in climate affected the total terrestrial carbon storage by using offline Lund-Potsdam-Jena dynamic global vegetation model (LPJ-DGVM). Our result shows that the total terrestrial carbon storage was reduced by $597 \mathrm{PgC}$ during the LGM, which corresponds to the emission of $282 \mathrm{ppm}$ atmospheric $\mathrm{CO}_{2}$. In the LGM experiments, the global carbon distribution is generally the same whether the vegetation feedback to the atmosphere is included or not. However, the inclusion of veg-
\end{abstract}

etation feedback causes substantial terrestrial carbon storage change, especially in explaining the lowering of atmospheric $\mathrm{CO}_{2}$ during the LGM.

\section{Introduction}

Paleoenvironmental reconstructions indicate a cold period around $21000 \mathrm{yr}$ ago, known as the Last Glacial Maximum (LGM), which is characterized by the huge extension of an ice sheet and lower atmospheric $\mathrm{CO}_{2}$ concentration. Reconstruction indicates that two huge ice sheets covered the northern part of the North American continent and northern Europe (Peltier, 1994, 2004). An equivalent amount of sea water is removed from the LGM ocean, so that sea level during the LGM is lower by 120 to $150 \mathrm{~m}$ than that of the presentday (Yokoyama et al., 2000). Paleo-ocean reconstruction shows about 2 to $3{ }^{\circ} \mathrm{C}$ cooling of the sea-surface temperature compared to the present-day in the tropical ocean and more than $10^{\circ} \mathrm{C}$ cooling in high latitudes (CLIMAP Project Members, 1976, 1984; Kucera et al., 2005; Waelbroeck et al., 2009). Pollen-based reconstruction also indicates more than $10^{\circ} \mathrm{C}$ cooling of ice-free land in North America and Europe (Bartlein et al., 2011). A cooler climate reduces precipitation, thus the land surface is drier than at present-day (Kohfeld and Harrison, 2000; Yu et al., 2000). Reconstructed information from ice-core components indicates that the atmospheric $\mathrm{CO}_{2}$ concentration during the LGM is about $185 \mathrm{ppm}$ (Jouzel et al., 1993; Monnin et al., 2001), which is $100 \mathrm{ppm}$ lower than it is in preindustrial times (285 ppm). Due to these cool, dry, and low- $\mathrm{CO}_{2}$ conditions, the vegetation 
distribution during the LGM is different from that of today in that it included an expanded arid area, a southward shift of the boreal forest belt, and a southward expansion of tundra (Prentice and Webb, 1998; Prentice and Jolly, 2000; Prentice and Harrison, 2009).

The paleoclimate modeling community tried to reproduce the LGM climate by using atmosphere general circulation models (AGCMs) and coupled atmosphere-ocean general circulation models (AOGCMs) in the Paleoclimate Modeling Intercomparison Project (PMIP). The results of the PMIP show that general circulation models (GCMs) are generally able to reproduce consistent cooling (Joussaume and Taylor, 2000; Braconnot et al., 2007). The paleovegetation distribution during the LGM is also investigated, using vegetation models with GCM results as input. This predicted qualitatively consistent vegetation changes with climate change in the LGM (Harrison and Prentice, 2003; Prentice et al., 2011). To introduce vegetation-climate feedback into GCMs, coupled atmosphere-ocean-vegetation GCMs (AOVGCMs) are developed. By using the AOVGCMs for the LGM experiments, these models well reproduce both climate and vegetation change in the LGM compared to the present-day (Wyputta and McAvaney, 2001; Ganopolski, 2003; Crucifix et al., 2005a; Crucifix et al., 2005b; Crucifix and Hewitt, 2005; Jahn et al., 2005; Henrot et al., 2009). These results reveal how changes in the land surface during the LGM contributes to the climate through changes of surface heat and water balance. Dust emission change due to vegetation change is also noted as an important factor of the vegetation during the LGM (Mahowald et al., 2006; Takemura et al., 2009).

Another aspect of vegetation change during the LGM is the change in the carbon cycle that affects atmospheric $\mathrm{CO}_{2}$ concentration. Not only the distribution of vegetation but also the strength of photosynthesis and soil carbon decomposition are important factors in terrestrial carbon distribution (Gerber et al., 2004; Prentice and Harrison, 2009). As far as the terrestrial carbon storage, reconstruction indicates a 300 to $700 \mathrm{PgC}$ reduction during the LGM (Bird et al., 1994), and estimation by LGM simulation with GCMs shows almost the same range of terrestrial carbon reduction (Prentice et al., 1993; Friedlingstein et al., 1995; François et al., 1998, 1999; Kaplan et al., 2002; Otto et al., 2002; Köhler and Fischer, 2004; Köhler et al., 2005; Ciais et al., 2011). For this kind of prediction of past terrestrial carbon storage including LGM, it is usual to use a dynamic global vegetation model (Joos et al., 2004). The uncertainty around the amount of terrestrial carbon stored during the LGM is thus larger than $200 \mathrm{PgC}$, which is equivalent to a reduction in the atmosphere of $100 \mathrm{ppm} \mathrm{CO}_{2}$ (Jouzel et al., 1993; Monnin et al., 2001). If we consider the sea level change during the LGM, about $200 \mathrm{PgC}$ could have been stored in the exposed continental shelf (Faure et al., 1996; Zeng, 2003; Montenegro et al., 2006), and the uncertainty in this may be comparable to that of the change in atmospheric $\mathrm{CO}_{2}$.
As shown above, there is uncertainty in the amount of change in terrestrial carbon, but it is important for understanding the LGM environment, especially the change in atmospheric $\mathrm{CO}_{2}$. In the present study, we newly apply a bias correction procedure in a running AOVGCM to reduce unrealistic vegetation feedback caused by temperature and precipitation bias. Then we investigate the climate of the LGM, the vegetation feedback onto the climate and the resultant equilibrium carbon storage with this newly constructed bias-corrected AOVGCM in order to quantify vegetationatmosphere feedback in the LGM and also quantify which aspect of the LGM influences the terrestrial carbon storage in the LGM. To save integration time, we actually use a slabocean instead of a full ocean general circulation model as a component of our AOVGCM. We also run several offline vegetation model experiments to obtain the equilibrium carbon storage which corresponds to climate of these AOVGCM experiments as input to an offline experiment. In the present study, we separate difference of terrestrial carbon storage into three kinds: response to the LGM climate, washout by icesheet coverage, and the new stock on the exposed continental shelf. We also apply the AOGCM for the LGM in order to evaluate the vegetation-climate feedback during the LGM and to use the equilibrium climate as input to the vegetation module, and also to estimate how vegetation evaluation after the AOGCM differs from the result that was consistent with those of the AOVGCM.

\section{Model description}

\subsection{Model components}

In the present study, a coupled vegetation general circulation model MIROC-LPJ (O'ishi and Abe-Ouchi, 2011) is used. The atmosphere component of the MIROC-LPJ is CCSR/NIES/FRCGC AGCM (Center for Climate System Research/National Institute for Environmental Studies/Frontier Research Center for Global Change atmospheric general circulation model), which is the same as the atmospheric part of an atmosphere-ocean coupled GCM known as the Model for Interdisciplinary Research on Climate (MIROC) (Hasumi and Emori, 2004) that contributed to the fourth assessment report of the Intergovernmental Panel on Climate Change (IPCC AR4)(Meehl et al., 2007).

The dynamical vegetation component is the LundPotsdam-Jena Dynamic Global Vegetation Model (LPJDGVM) (Sitch et al., 2003), which predicts the distribution of ten vegetation types (plant functional types, PFTs) based on the bioclimatic limits, photosynthesis, respiration, carbon allocation, plant establishment, growth, turnover, mortality, and competition among the PFTs. In the MIROC-LPJ, an interactive coupling between the atmosphere and the change in land vegetation is introduced as follows: the monthly mean surface temperature, precipitation, and cloud cover predicted 
by the atmosphere component are used as the input to the LPJ-DGVM. The terrestrial heat and energy component of MIROC is Minimal Advanced Treatments of Surface Interaction and RunOff (MATSIRO; Takata et al., 2003), which does not include a dynamical vegetation component. In this version of MIROC, fractional coverage of different vegetation types is not yet included and just one vegetation type represents one land grid cell. Hence we coupled MIROC and LPJ-DGVM in a very simple way. LPJ-DGVM only predicts representative vegetation type (which is classified in MATSIRO) for every grid cell annually. Since LPJ-DGVM is able to predict the distribution of ten PFT types, we translate this combination of PFTs into MATSIRO vegetation classification with some additional information (leaf area index (LAI), soil moisture, growing degree days (GDD), net primary productivity (NPP); see O'ishi and Abe-Ouchi, 2009, for detail). This translated vegetation distribution does not include exact information from LPJ-DGVM but substantial large-scale characteristics of vegetation distribution. Since LPJ-DGVM does not handle human-induced change (e.g crops), all "vegetation" in the present study is inevitably potential vegetation. Then MATSIRO solves land surface heat and energy budget and balance equations according to the vegetation type (translated from LPJ-DGVM) and corresponding parameters which are based on MATSIRO vegetation classification. We simplified LAI seasonality as a simple sine curve which is also based on MATSIRO vegetation classification. Thus in MIROC-LPJ, MATSIRO is able to work if a vegetation type is given in a grid cell whether it is from LPJ-DGVM or not. We can also choose a specific prescribed vegetation distribution instead of coupling LPJ-DGVM (this kind of experiment is noted as fixed vegetation in Sect. 3.1).

The original MIROC includes a full ocean dynamical component COCO (Hasumi, 2006), but it will take too long a numerical integration to equilibrate because atmosphereocean-vegetation interactive system may have several hundred years (perhaps $1000 \mathrm{yr}$ or more) of time scale to achieve the equilibrium. In the present study, we actually choose a slab-ocean model for an ocean component of MIROC-LPJ instead of the COCO to save integration time. We assume seasonality of ocean heat transport to predict distribution of sea surface temperature and sea-ice.

In all experiments, the horizontal and vertical resolutions of the atmospheric correspond to T42 $\left(2.8 \times 2.8^{\circ}\right.$ longitude $\times$ latitude) and 20 layers, respectively. Horizontal resolution of slab-ocean component is also T42.

\subsection{Bias correction}

The MIROC generally reproduces the climate of today and the 20th century, but there is an unavoidable temperature and precipitation bias in the MIROC compared to the observations as a benchmark (The European Centre for MediumRange Weather Forecasts (ECMWF) ERA40 temperature (Uppala et al., 2005) and the CPC Merged Analysis of Pre- cipitation (Xie and Arkin, 1997)). This bias can cause an incorrect distribution of vegetation in the preindustrial and present-day, and thus can cause a unrealistic response of the atmosphere to the change of vegetation distribution in the paleo-setting experiments. Hence we introduce a bias correction into the MIROC-LPJ. The monthly temperature and precipitation from the AGCM are modified by using a reference model experiment and observed data, in order to remove the bias before these variables are passed to the LPJ-DGVM as follows:

$T_{\text {input }}=T_{\text {model }}-\left(T_{\mathrm{PD}, \text { model }}-T_{\mathrm{obs}}\right)$

$P_{\text {input }}=P_{\text {model }} \cdot \frac{P_{\text {obs }}}{P_{\mathrm{PD}, \text { model }}}$

where $T_{\text {model }}$ and $P_{\text {model }}$ are surface air temperature and precipitation predicted in an MIROC-LPJ experiment. $T_{\mathrm{obs}}$ and $P_{\text {obs }}$ are present-day observational surface air temperature and precipitation which correspond to ECMWF ERA40 and CMAP, respectively). $T_{\mathrm{PD} \text {,model }}$ and $P_{\mathrm{PD} \text {,model }}$ are surface air temperature and precipitation, respectively, predicted in the present-day MIROC-LPJ experiment which adopts an atmospheric $\mathrm{CO}_{2}$ concentration of $345 \mathrm{ppm}$ without this bias correction. Hereafter we can correct temperature and precipitation bias in a running GCM experiment. There is still discussion whether to apply the bias correction and how it would be done (Hagemann et al., 2011; Ehret et al., 2012). In the present study, we apply bias correction on monthly mean temperature and precipitation when LPJ-DGVM predicts vegetation distribution since the coupling between MIROC and LPJ-DGVM is very simple, as shown in the previous subsection. There is no problem as far as conservation of energy and water in the land surface process of the MIROC-LPJ. On the other hand, there can be an uncertainty caused by the introduction of bias correction. We assume that model bias in the present-day is as same as preindustrial, LGM, future,... etc. This assumption is not exactly guaranteed because we do not know the actual temperature and precipitation in these other periods. Under other climatic conditions, the model bias may differ from that of the presentday. However, we consider this assumption as a good firstorder approximation to evaluate more correct responses of atmosphere to vegetation change. Here we show some examples. Since MIROC-LPJ has a warm bias over the land, the boreal forest/tundra boundary in the control preindustrial experiment is located further north compared to the actual boundary if we do not apply bias correction (see Fig. A1a in the Appendix). This underestimation of tundra in the control preindustrial experiment may cause weaker climatevegetation feedback in a warm climate. O'ishi and AbeOuchi (2011) show the bias-corrected vegetation change in the mid-Holocene is able to explain reconstructed warming in northern high latitude at that time. The southern boundary of boreal forest is also located farther north and an unrealistic 
gap (covered with grass) appears between boreal and temperate in the control preindustrial experiment if we do not apply bias correction (Fig. A1a). This unrealistic gap will expand northward if we try to carry out various kinds of warming simulations and cause more discrepancy between the control and warming experiments. When we try to run the LGM simulation (Fig. A1b), there is a northward shift of boreal forest in Siberia in spite of the cool climate. This strange result is considered to be induced by the combined effect of a warm bias, decrease of snow cover and a warming due to the stationary wave effect of the Scandinavian ice sheet (Abe-Ouchi et al., 2007).

\subsection{Carbon balance}

The LPJ-DGVM (Sitch et al., 2003) is able to predict four types of biomass storage (leaf, heartwood, sapwood, and root) for every PFT, carbon pools that correspond to different time scales of decomposition, in the coupled MIROC-LPJ. At first, the net primary productivity (NPP) is calculated by the gross primary productivity, autotrophic respiration and growth cost of production. Then NPP is distributed to four biomass carbon pools shown above. Biomass is moved to soil carbon pool by turnover, fire event, heat stress and change of bioclimatic limits. The soil carbon is separated into three pools with different time scale of decomposition. The decomposition of soil carbon depends on temperature, soil moisture and time scale of decomposition. LPJ-DGVM employs the relation between temperature and soil carbon decomposition from Lloyd and Taylor (1994).

Different from full carbon coupled GCM experiments (e.g. Faloon et al., 2012), feedback through carbon balance is not introduced in the MIROC-LPJ and both the GCM and LPJ-DGVM are forced by a given level of atmospheric $\mathrm{CO}_{2}$. This is because we intend to evaluate the direct effect of vegetation change as land surface boundary condition through water and heat balance upon the climate. Prediction of the equilibrium terrestrial carbon is completed by an offline LPJ-DGVM experiment using as input the result of the MIROC-LPJ equilibrium climate. These offline experiments are conducted because it takes many integration years to equilibrate the terrestrial carbon storage in a coupled MIROC-LPJ setup (see Experimental settings, below). Another reason is the limitation of MIROC itself because this version of MIROC (and therefore MIROC-LPJ) does not include ocean carbon cycle.

\section{Experimental settings}

\subsection{Coupled GCM experiments}

Two experiments are preformed by using the MIROC-LPJ, as shown in Table 1. In the preindustrial control experiment, $\mathrm{AOV}(\mathrm{PI})$, the preindustrial level of atmospheric $\mathrm{CO}_{2}$ $(285 \mathrm{ppm})$ and present-day orbital parameters are employed.
In the LGM experiment, AOV(LGM), the LGM level of atmospheric $\mathrm{CO}_{2}(185 \mathrm{ppm})$, the LGM orbital parameters, and ICE-5G ice sheets (Peltier, 2004) are taken from the Paleoclimate Modeling Intercomparison Project 2 (PMIP2) protocol (Braconnot et al., 2007). The expanded LGM land cover $\left(+23 \times 10^{12} \mathrm{~m}^{2}\right)$ is employed by assuming a $150 \mathrm{~m}$ sea level descent which is the largest estimation (Yokoyama et al., 2000) in order to evaluate the upper limit of the effect of difference of coastline, especially for vegetation distribution and carbon storage. Other green house gases (GHGs), $\mathrm{CH}_{4}$, $\mathrm{N}_{2} \mathrm{O}, \mathrm{CFC}$ and $\mathrm{O}_{3}$ are set to the preindustrial values because we intend to extract response of climate and vegetation to difference of atmospheric $\mathrm{CO}_{2}$. These experiments are integrated over about $400 \mathrm{yr}$ including spin-up, which is long enough to reach equilibrium for both vegetation distribution and climate.

An additional set of experiments, $\mathrm{AO}(\mathrm{PI})$ and $\mathrm{AO}(\mathrm{LGM})$, are performed to investigate the effect of vegetation change on climate. In these experiments, the model does not refer the LPJ-DGVM, and the vegetation map is fixed to the equilibrium state of the AOV(PI) experiment. For this, we first extract MATSIRO vegetation type which appeared most frequently during the last $50 \mathrm{yr}$ of $\mathrm{AOV}(\mathrm{PI})$ in each grid cells. This vegetation map is considered to be a representative vegetation distribution which is given to MATSIRO as a surface boundary condition during the last $50 \mathrm{yr}$ of $\mathrm{AOV}(\mathrm{PI})$. Then we run MIROC-LPJ with this vegetation map instead of LPJDGVM's prediction. As noted in Sect. 2.1, MIROC-LPJ is able to run without vegetation index from LPJ-DGVM since vegetation type is used to choose a set of parameters which is defined for every vegetation type. In $\mathrm{AO}(\mathrm{LGM})$, we use the same coastline and ice-sheet distribution as AOV(LGM). Thus, in order to prepare a vegetation map in the AO(LGM), an offline LPJ-DGVM experiment is performed using the LGM coastline with the AOV(PI) result as input. This map is the same as the resultant vegetation map of the AOV(PI) for those land grid cells that are shared by both the preindustrial and the LGM. Results of the last $50 \mathrm{yr}$ in all experiments are used for the analysis since vegetation distribution and climate are sufficiently equilibrated with $400 \mathrm{yr}$ integration in both $\mathrm{AOV}(\mathrm{PI})$ and $\mathrm{AOV}(\mathrm{LGM})$.

\subsection{Offline LPJ-DGVM experiments}

\subsubsection{Sensitivity experiments}

We perform six sensitivity experiments, as shown in Table 2 , using the LPJ-DGVM in an offline mode. In order to compare the impact of $\mathrm{CO}_{2}$ concentration, precipitation, and temperature on vegetation distribution during the LGM (which is similar method to Jones et al., 2004; Faloon et al., 2011), one or two factor(s) are set to the LGM value and the rest to the preindustrial for input to the LPJ-DGVM. Atmospheric $\mathrm{CO}_{2}$ values are as same as those of $\mathrm{AOV}(\mathrm{LGM})$ and $\mathrm{AOV}(\mathrm{PI})$. 
Table 1. Settings of the experiments performed in this study.

\begin{tabular}{llllll}
\hline Experiment & $\mathrm{CO}_{2}$ level & Orbit & Vegetation & MIROC-LPJ & offline LPJ-DGVM \\
\hline $\mathrm{AOV}(\mathrm{PI})$ & $285 \mathrm{ppm}$ & 0ka & dynamic & $390 \mathrm{yr}$ & $1000 \mathrm{yr}$ \\
$\mathrm{AOV}(\mathrm{LGM})$ & $185 \mathrm{ppm}$ & LGM & dynamic & $400 \mathrm{yr}$ & $1000 \mathrm{yr}$ \\
$\mathrm{AO}(\mathrm{PI})$ & $285 \mathrm{ppm}$ & 0ka & fixed to AOV(PI) & $75 \mathrm{yr}$ & - \\
$\mathrm{AO}(\mathrm{LGM})$ & $185 \mathrm{ppm}$ & LGM & fixed to AOV(PI) & $50 \mathrm{yr}$ & $1000 \mathrm{yr}$ \\
\hline
\end{tabular}

Table 2. Settings of the offline sensitivity experiments performed in this study. Precipitation and temperature are taken from the $\mathrm{AOV}(\mathrm{LGM})$ and the AOV(PI), respectively.

\begin{tabular}{lllll}
\hline Experiment & $\mathrm{CO}_{2}$ & Precipitation & Temperature & integration \\
\hline $\mathrm{CP}$ & $185 \mathrm{ppm}$ & LGM & PI & $1000 \mathrm{yr}$ \\
$\mathrm{TC}$ & $185 \mathrm{ppm}$ & PI & LGM & $1000 \mathrm{yr}$ \\
$\mathrm{TP}$ & $285 \mathrm{ppm}$ & LGM & LGM & $1000 \mathrm{yr}$ \\
$T$ & $285 \mathrm{ppm}$ & PI & LGM & $1000 \mathrm{yr}$ \\
$P$ & $285 \mathrm{ppm}$ & LGM & PI & $1000 \mathrm{yr}$ \\
$C$ & $185 \mathrm{ppm}$ & PI & PI & $1000 \mathrm{yr}$ \\
\hline
\end{tabular}

Temperature and precipitation are taken from the last $50 \mathrm{yr}$ time series of both $\mathrm{AOV}(\mathrm{LGM})$ and $\mathrm{AOV}(\mathrm{PI})$ to include the interannual variability, and used 20 times repeatedly for $1000 \mathrm{yr}$ of integration; the results of the last $100 \mathrm{yr}$ are used for analysis.

\subsubsection{Carbon equilibrium}

Since changes in soil carbon have a long time scale, approximately four hundred years of AOVGCM integration in Table 1 is too short to equilibrate the total terrestrial carbon storage. In analogy to the experiments described in Sect. 3.2.1 (Table 2), we performed further $1000 \mathrm{yr}$-long offline experiments but now using the full forcings derived from our two AOVGCM experiments. In order to evaluate the equilibrium carbon storage in the LGM and the preindustrial era, offline LPJ-DGVM experiments are performed, using the result of the last $50 \mathrm{yr}$ time series in the two AOVGCM experiments as input and letting them run for the equivalent of $1000 \mathrm{yr}$ by giving climate variables 20 times repeatedly. The vegetation map and the climate are equilibrated far faster than terrestrial carbon storage, so that it is not necessary to integrate a coupled MIROC-LPJ until carbon storage is equilibrated. This is the same procedure as was adopted in a previous study (O'ishi and Abe-Ouchi, 2009). We also examine offline LPJ-DGVM experiments, using the result of the AO(LGM) experiment as input. This experiment corresponds to the offline diagnosis of carbon storage using a GCM result without vegetation feedback as well as Harrison and Prentice (2003). The last $100 \mathrm{yr}$ of resultant variables are used for analysis. Carbon storages/fluxes are just averaged over the last $100 \mathrm{yr}$. Hence vegetation distribution is predicted by vegetation indices with interannual variability, we choose and show the most dominant vegetation index during the last $100 \mathrm{yr}$ as a representative vegetation index.

\section{Results}

\subsection{Vegetation distribution}

In the AOV(LGM), there are some typical changes in the vegetation pattern compared to the AOV(PI) (Fig. 1a and b). We first discuss changes in vegetation as determined according to the MATSIRO classification. In the south of the Scandinavian and Laurentide ice sheets, boreal forests shift southward and tundra appears. In eastern Siberia, boreal forests retreat southward and the southern boundary of tundra is relocated to $50 \mathrm{~N}$. The southern boundary of the boreal forests also shifts southward in North America and China. In the downstream region of the Scandinavian ice sheet, a slight northward shift of boreal forest appears. Total reduction of the area of boreal forest is $14.0 \times 10^{12} \mathrm{~m}^{2}$ and expansion of tundra is $6.2 \times 10^{12} \mathrm{~m}^{2}$. Expansion of desert is seen in Central Asia, North and South Africa, and North America, totaling $15.1 \times 10^{12} \mathrm{~m}^{2}$ of increase. In the tropical region, the tropical forest shrinks, and savanna or grassland appears or increases, especially in Africa. Tropical forest covers the exposed continental shelf over the maritime continent. The continental shelf of the East China Sea to south of the Japan Sea is covered by temperate forest. The East Siberian Sea and north of the Bering Sea turns into tundra. According to LPJ-DGVM PFT classification, a fraction of grass PFTs in LPJ-DGVM increase in high latitude (Fig. 1c) and decreases in the central Eurasia. A fraction of forest shows a decrease in both northern high latitudes and tropical regions (Fig. 1d). The NPP also shows a drastic change (Fig. 3a and h). The global total annual NPP during the LGM and the preindustrial are 44.0 $\mathrm{PgC} \mathrm{yr}^{-1}$ and $59.5 \mathrm{PgC} \mathrm{yr}^{-1}$, respectively (Table 3 ). Reduction of $5.4 \mathrm{PgC} \mathrm{yr}^{-1}$ occurs due to covering by the expanded ice sheet, and an increase of $7.5 \mathrm{PgC} \mathrm{yr}^{-1}$ occurs on the exposed continental shelf due to a change in sea level (these values are not shown in the table). In the AOV(LGM), a large part of the total reduction of NPP is seen in the forest region (see Fig. 3h) compared to AOV(PI).

By performing additional sensitivity experiments for the LGM using the offline LPJ-DGVM, but setting one or two of the forcing parameters to preindustrial values, it is revealed that these vegetation changes are caused by individual 
(a) Vegetation distribution in $\mathbf{A O V}(\mathbf{P I})$

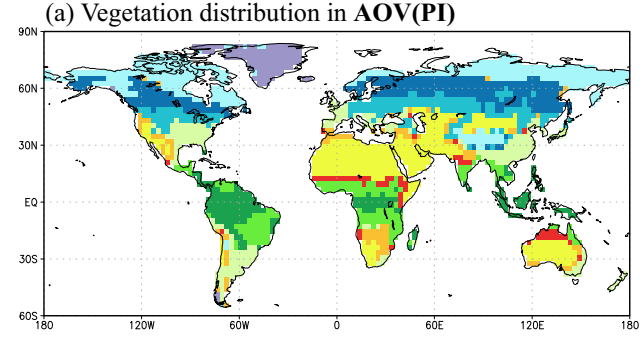

(b) Vegetation distribution in $\mathbf{A O V}(\mathbf{L G M})$

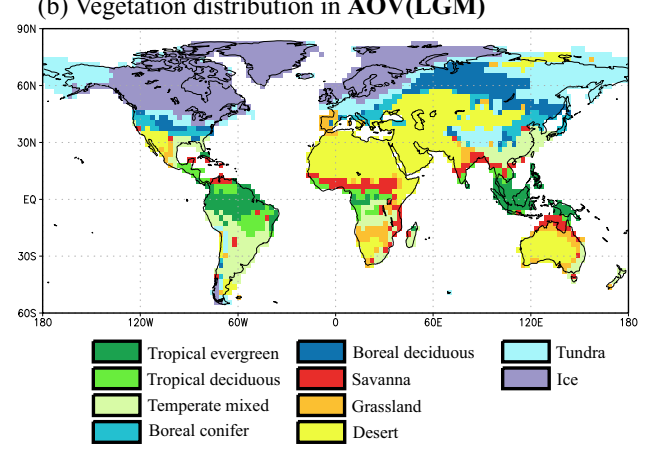

(c) Difference of grass fraction $[\mathrm{AOV}(\mathbf{L G M})$ - AOV(PI)]

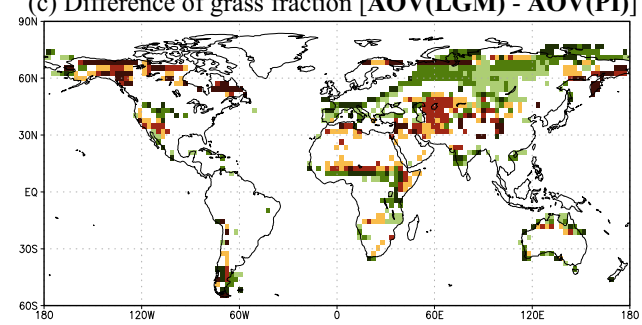

(d) Difference of forest fraction [AOV(LGM) - AOV(PI)]

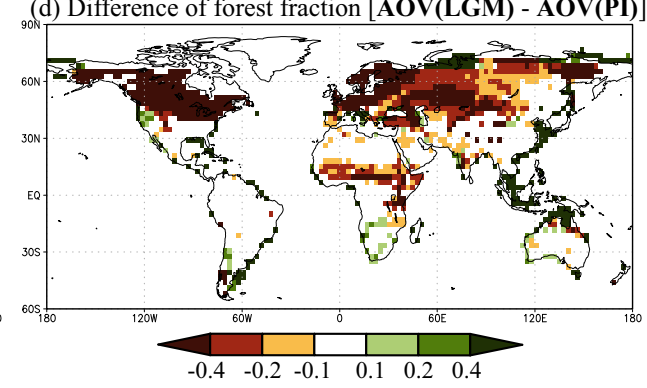

Fig. 1. Vegetation distribution obtained in (a) AOV(PI) and (b) AOV(LGM) according to MATSIRO classification. Difference of fractional coverage in (c) grass and (d) forest between AOV(LGM) and AOV(PI) which are from PFT-based variables in the LPJ-DGVM.

Table 3. Equilibrium global NPP $\left(\mathrm{PgC} \mathrm{yr}^{-1}\right)$ and global biomass, soil carbon and total carbon storage $(\mathrm{PgC})$. The sum of four biomass carbon pools is shown as "biomass". The sum of three soil carbon pools is shown as "soil carbon". Total carbon is sum of biomass and soil carbon. Values in the parentheses do not include the LGM icesheet area in the preindustrial nor continental shelf area in the LGM to extract pure response to climate and atmospheric $\mathrm{CO}_{2}$. Result of $\mathrm{AOV}(\mathrm{PI})$ and upper column of other experiments are absolute values. In lower columns, values denote absolute differences with respect to $\mathrm{AOV}(\mathrm{PI})$. The last digit can include a rounding error.

\begin{tabular}{lrrrr}
\hline Experiment & NPP & Biomass & Soil carbon & Total \\
\hline AOV(PI) & $59.5(54.0)$ & $1082(973)$ & $1368(1088)$ & $2450(1062)$ \\
AOV(LGM) & $44.0(36.5)$ & $828(672)$ & $1025(888)$ & $1853(1560)$ \\
& $-15.5(-17.6)$ & $-254(-301)$ & $-343(-200)$ & $-597(-502)$ \\
AO(LGM) & $44.6(36.7)$ & $823(660)$ & $1009(861)$ & $1831(1522)$ \\
& $-14.9(-17.3)$ & $-259(-313)$ & $-359(-227)$ & $-619(-540)$ \\
CP & $44.2(36.7)$ & $808(653)$ & $853(765)$ & $1661(1417)$ \\
& $-15.3(-17.4)$ & $-274(-321)$ & $-515(-323)$ & $-789(-645)$ \\
TC & $48.5(40.2)$ & $933(760)$ & $1207(1033)$ & $2140(1793)$ \\
& $-11.0(-13.8)$ & $-149(-213)$ & $-161(-55)$ & $-310(-269)$ \\
TP & $57.7(47.9)$ & $1068(875)$ & $1316(1141)$ & $2384(2016)$ \\
& $-1.8(-6.2)$ & $-14(-98)$ & $-52(+53)$ & $-66(-46)$ \\
$T$ & $64.1(53.2)$ & $1218(1001)$ & $1503(1298)$ & $2721(2299)$ \\
& $+4.6(-0.8)$ & $+136(+28)$ & $+135(+210)$ & $+271(+237)$ \\
$P$ & $59.7(49.5)$ & $1047(856)$ & $1101(984)$ & $2148(1840)$ \\
& $+0.2(-4.5)$ & $-35(-117)$ & $-267(-104)$ & $-302(-222)$ \\
$C$ & $49.3(41.0)$ & $929(761)$ & $961(859)$ & $1890(1620)$ \\
& $-10.2(-13.0)$ & $-153(-212)$ & $-407(-229)$ & $-560(-442)$ \\
\hline
\end{tabular}

aspects of environmental change during the LGM. These results are compared with AOV(PI) and AOV(LGM) in Fig. 2 according to the MATSIRO classification. Of course an offline experiment is conceptually different from an online experiment, however, the response signals to different temperature, precipitation and $\mathrm{CO}_{2}$ concentration are far larger than the inconsistency between offline and online. By comparing the left side of Fig. 2 (a-d, preindustrial temperature) and the right side of Fig. 2 (e-h, LGM temperature), it is shown that the temperature changes during the LGM mainly dominated the distribution of forest/tundra boundary. Cooling in high latitudes shifts the boundary of the forest/tundra to the south. Around the Scandinavian and Laurentide ice sheets, tundra appears between the ice sheet and the boreal forests, due to cooling, in all offline experiments with LGM temperature (Fig. 2e-h). In the tropical regions, cooling compensated for expansion of savanna, which is due to less precipitation and lower $\mathrm{CO}_{2}$ during the LGM but a relatively higher preindustrial temperature. For example, with LGM temperature (Fig. 2h), savanna is replaced by forest, compared to correspondent experiments with preindustrial temperature (Fig. 2d). This tendency is also seen in other combinations of precipitation and $\mathrm{CO}_{2}$ (e.g comparison between Fig. 2a and e, between Fig. $2 b$ and $f$ and between Fig. $2 c$ and g). This is consistent with NPP changes. In Fig. 3e, reduction of NPP in tropical region is smaller due to decrease of autotrophic respiration if we apply LGM temperature.

By comparing Fig. 2b, d, f and h (LGM precipitation) and Fig. 2a, c, e and g (PI precipitation) we see that precipitation changes during the LGM mainly dominated the distribution 
(a) $\operatorname{AOV}(\mathrm{PI})$

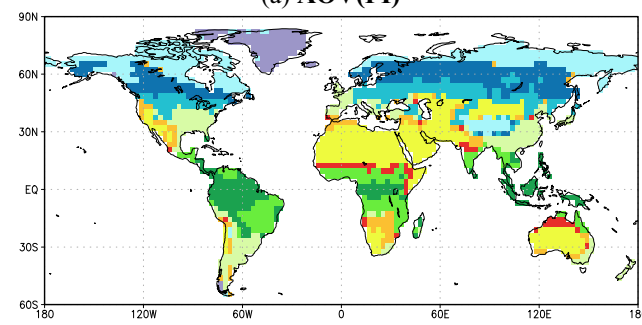

(b) offline exp. $\mathbf{P}$

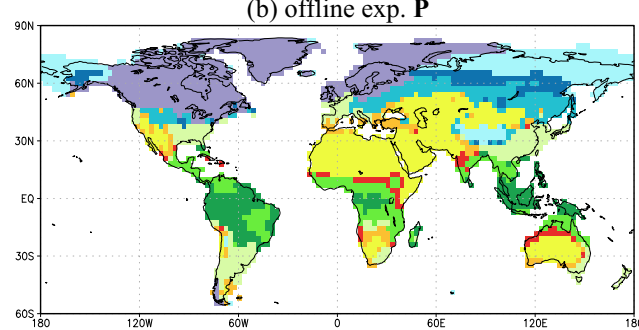

(c) offline exp. $\mathbf{C}$

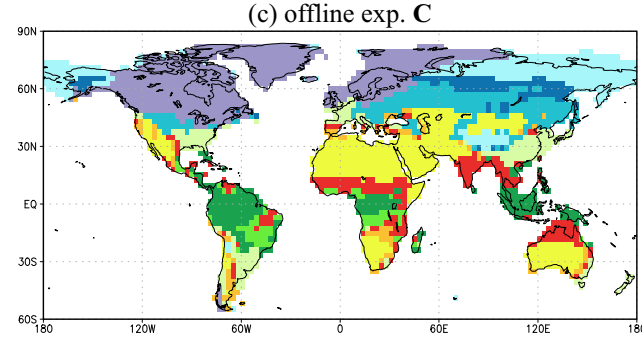

(d) offline exp. $\mathbf{C P}$

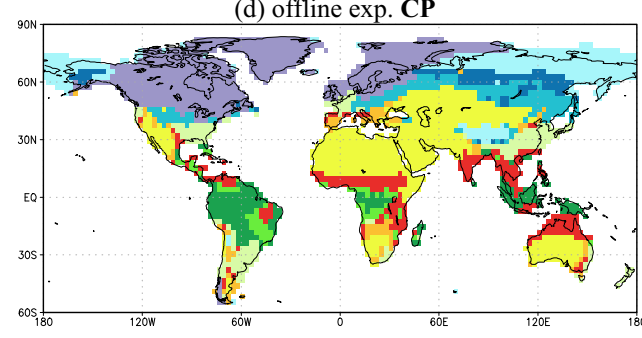

(e) offline exp. T

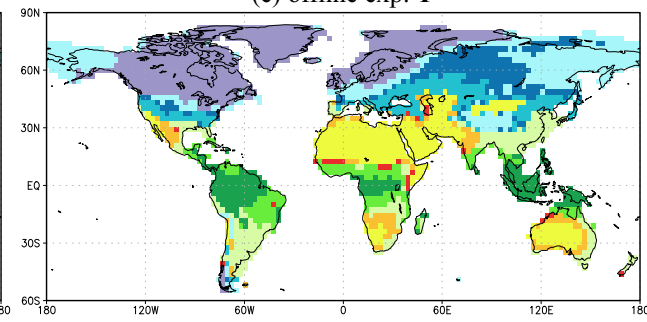

(f) offline exp. TP

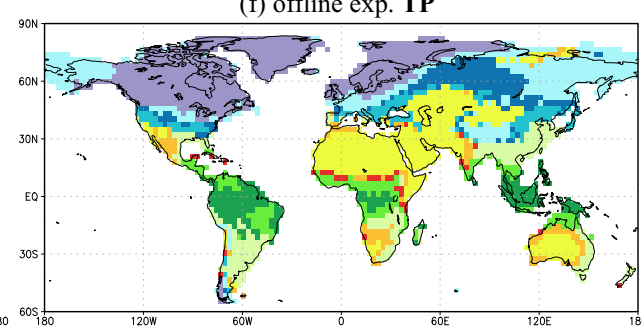

(g) offline exp. TC

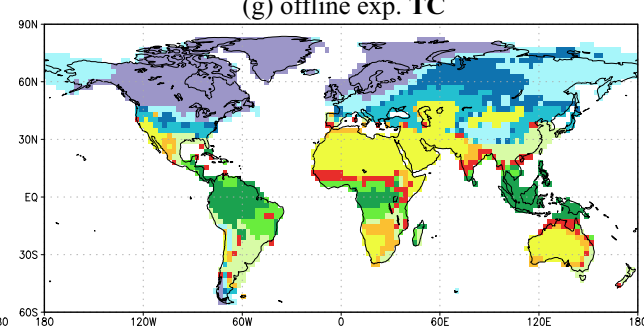

(h) AOV(LGM)

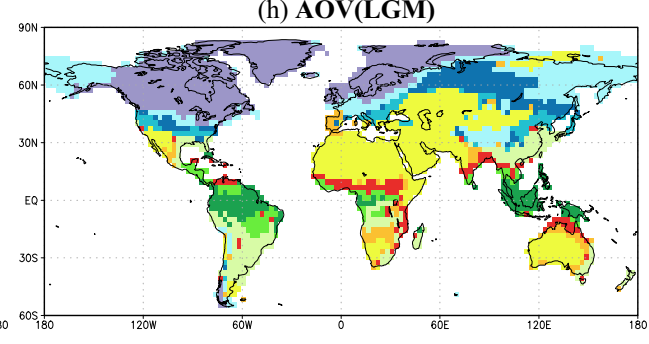

Fig. 2. Vegetation distribution obtained in (a) AOV(PI) and (h) AOV(LGM) (they are as same as Fig. 1 and shown again for convenience). Vegetation distribution obtained in offline sensitivity experiments (b) $P$, (c) $C$, (d) CP, (e) $T$, (f) TP and (g) TC according to MATSIRO classification.

of desert and savanna. Especially the boundary between boreal forests and desert is formed by LGM precipitation. In the central Eurasia continent, less precipitation during the LGM expands deserts, especially north and west of the Caspian Sea, which had the largest decrease in precipitation on the Eurasian continent. The Gobi and Taklamakan deserts expands slightly northward. The boreal forests of the Pamir plateau and Tian Shan Mountains turns into desert, due to the decrease in precipitation. However, the total shift of this forest/desert boundary is not achieved solely by LGM precipitation (Fig. 2b) but additional combined effect with $\mathrm{LGM} \mathrm{CO}_{2}$ (Fig. 2d) is also important. The expansion of desert and savanna corresponds to change of NPP. Figure $3 \mathrm{~b}$ indicates major reduction of NPP in central Eurasia and Sahel in Africa.
Other experiments with LGM precipitation (Fig. 3d, f and h) show the same pattern of NPP change in these regions.

By comparing Fig. 2c, d, g and h (with $\mathrm{LGM} \mathrm{CO} 2$ ) and Fig. 2a, b, e and $\mathrm{f}$ (with preindustrial $\mathrm{CO}_{2}$ ), we see that low $\mathrm{CO}_{2}$ during the LGM mainly dominated the distribution of savanna in the tropical region e.g. Sahel, South Africa and Australia (Fig. 2c for example). There is a slight expansion of desert due to decrease photosynthesis, but the NPP shows a substantial reduction due to the lower level of $\mathrm{CO}_{2}$ not only in the tropical region but also in temperate and boreal forests (Fig. 3c).

These results suggest that the dominant factors for vegetation during the LGM depend on regions. In high latitudes, low temperature in the LGM shows the major contribution to the location of boundary between boreal forest tundra. 

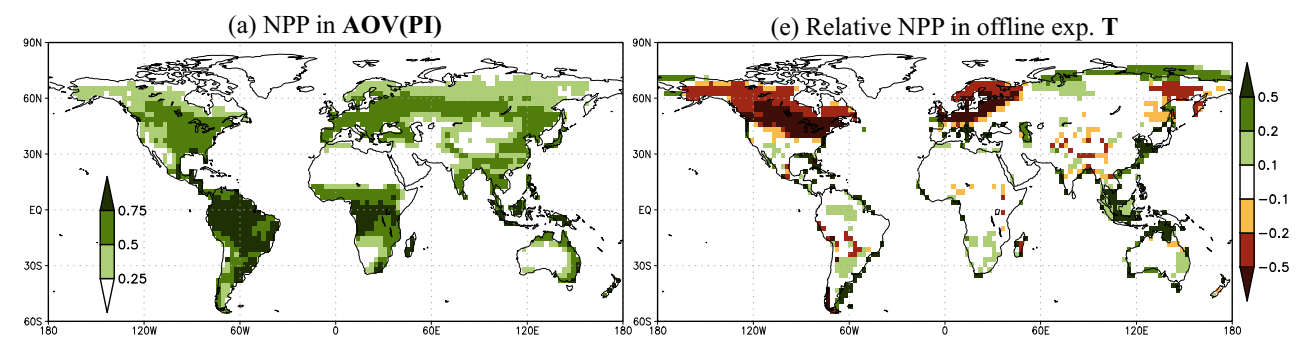

(b) Relative NPP in offline exp. $\mathbf{P}$
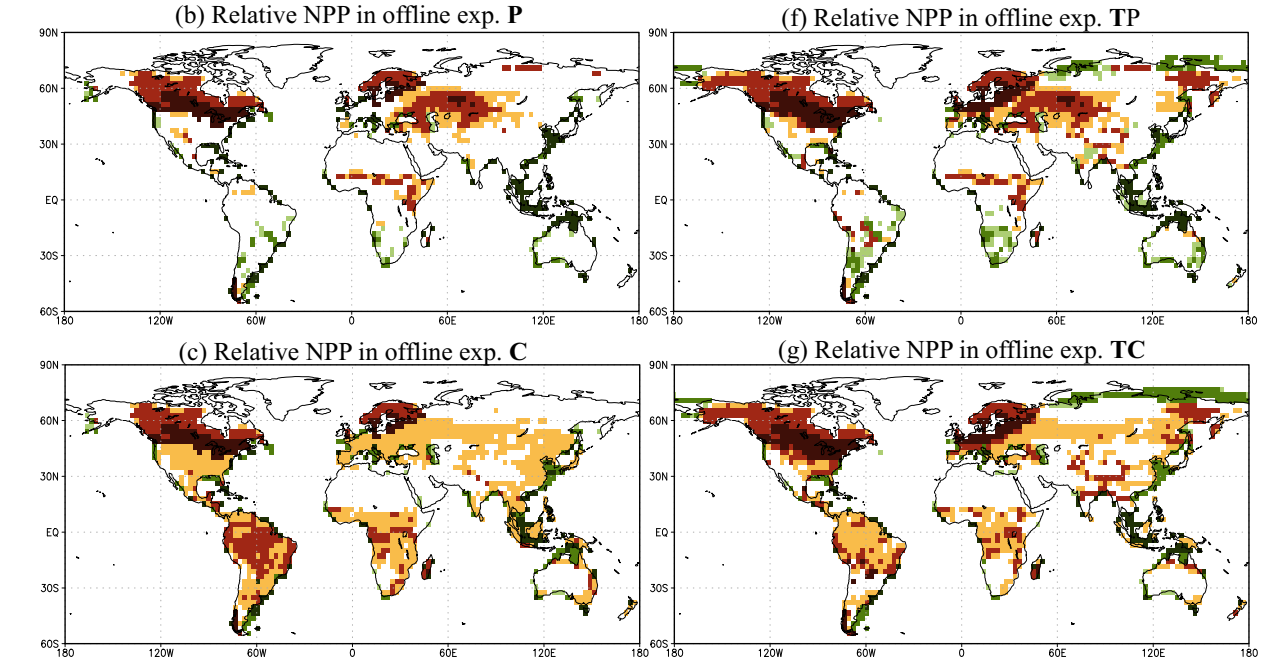

(g) Relative NPP in offline exp. TC

(d) Relative NPP in offline exp. CP

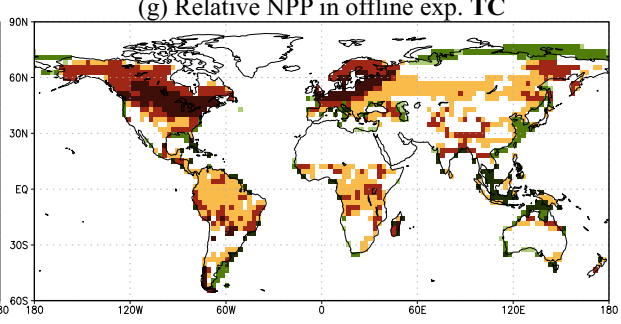

(h) Relative NPP in AOV(LGM)
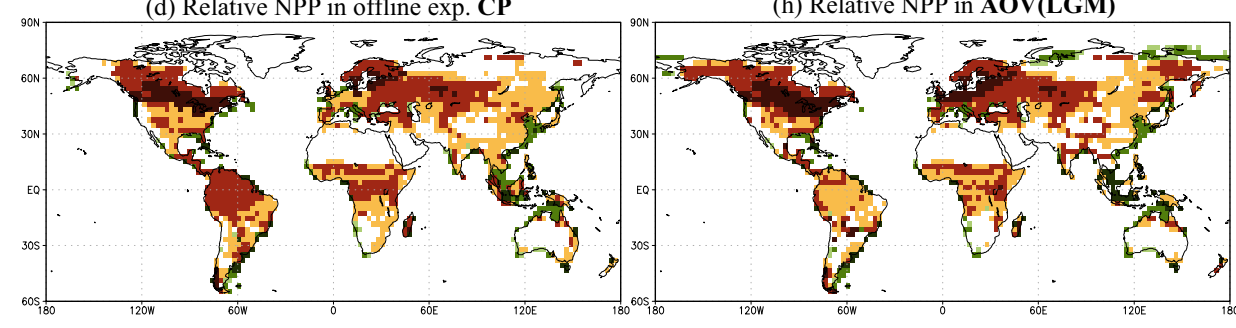

Fig. 3. Equilibrium net primary productivity (NPP) $\left[\mathrm{kg} \mathrm{m}^{-2} \mathrm{yr}^{-1}\right]$ in (a) $\mathrm{AOV}(\mathrm{PI})$ and absolute NPP differences with respect to AOV(PI) in offline experiments (b) $P$, (c) $C$, (d) CP, (e) $T$, (f) TP and (g) TC. Absolute NPP difference in AOV(LGM) with respect to AOV(PI) is shown in (h).

The other boundary between boreal forest and desert in midlatitudes is most influenced by precipitation decrease. Low $\mathrm{CO}_{2}$ levels also contribute to vegetation shift but the magnitude is smaller in mid-latitudes. In tropical areas, the lower atmospheric $\mathrm{CO}_{2}$ during the LGM only changes the vegetation into savanna, and it reduces the NPP, even when the vegetation distribution is unchanged. There are also synergy effects of the three different forcing factors. In Amazonia and Africa, temperate forest replaces tropical forest, so that the tropical regions shrink toward the equator. This is not only due to cooling but also to precipitation and $\mathrm{CO}_{2}$. The southward shift of the tundra/forest boundary in northeast China is not explained by a single variable. A synergy effect of temperature, precipitation, and $\mathrm{CO}_{2}$ causes the total response of vegetation in these regions. However, a total amount of these synergy effects is limited. The response of NPP, which explains vegetation change well, indicates that temperature, precipitation and $\mathrm{CO}_{2}$ effects are almost additive (Table 3 ). The sum of individual responses of NPP to temperature ( $T$, $\left.-0.8 \mathrm{PgC} \mathrm{yr}^{-1}\right)$, precipitation $\left(P,-4.5 \mathrm{PgC} \mathrm{yr}^{-1}\right)$ and $\mathrm{CO}_{2}$ $\left(C,-13.0 \mathrm{PgC} \mathrm{yr}^{-1}\right)$ is very close to that of total AOV(LGM) responses $\left(-17.6 \mathrm{PgC} \mathrm{yr}^{-1}\right)$. A synergy effect is seen between temperature and precipitation by comparing TP result $\left(-6.2 \mathrm{PgC} \mathrm{yr}^{-1}\right)$ with the sum of $T$ and $P$. Synergy of precipitation and $\mathrm{CO}_{2}\left(\mathrm{CP},-17.4 \mathrm{PgC} \mathrm{yr}^{-1}\right)$ shows close value to that of $\mathrm{AOV}(\mathrm{LGM})$. The $\mathrm{CO}_{2}$ effect on NPP seems to be additive to temperature and/or precipitation effect.

\subsection{LGM climate and impact of vegetation change}

In the $\mathrm{AOV}(\mathrm{LGM})$, the globally averaged $2 \mathrm{~m}$ air temperature is decreased by $4.88 \mathrm{~K}$ compared to the $\mathrm{AOV}(\mathrm{PI})$, due to orbital change, lowered atmospheric $\mathrm{CO} 2$, expansion of the ice sheets, and changes in vegetation. On the other hand, in 


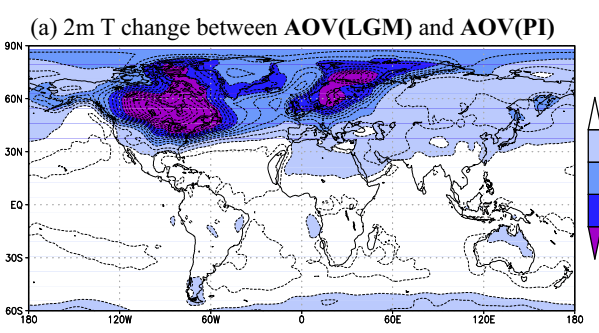

(b) Vegetation-induced $2 \mathrm{~m}$ T change

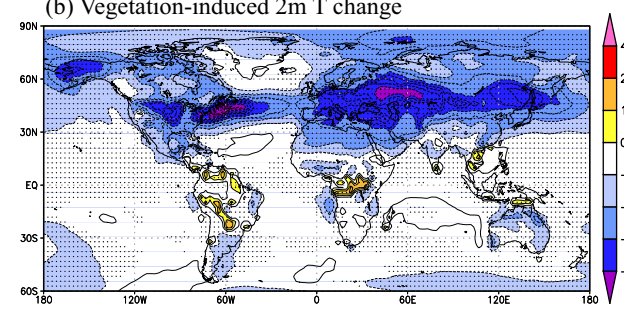

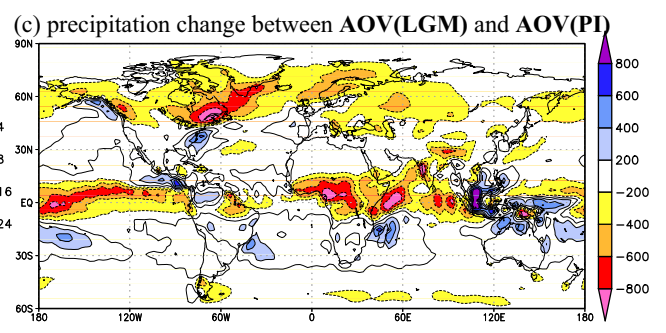

(d) Vegetation-induced precipitation change

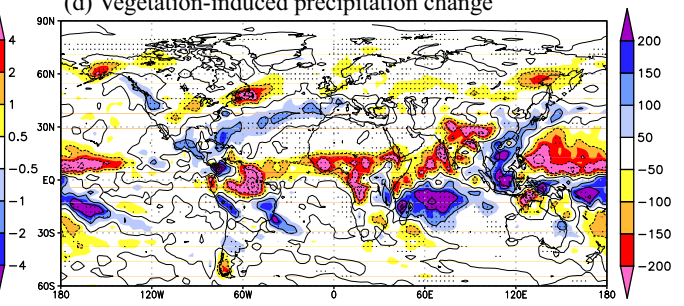

Fig. 4. Annual averaged $2 \mathrm{~m}$ temperature change $[\mathrm{K}]$ (the contour interval is $2 \mathrm{~K}$ ) and precipitation change [mm $\mathrm{yr}^{-1}$ ] (the contour interval is $100 \mathrm{~mm} \mathrm{yr}^{-1}$ ) in the experiment AOV(LGM) from AOV(PI) are shown in panels (a) and (c), respectively. Contribution of vegetation change in panels (b) ( $2 \mathrm{~m}$ temperature, the contour interval is $1 \mathrm{~K}$ ) and (d) (precipitation, the contour interval is $100 \mathrm{~mm} \mathrm{yr}^{-1}$ ) are calculated from $(\mathrm{AOV}(\mathrm{LGM})-\mathrm{AOV}(\mathrm{PI}))-(\mathrm{AO}(\mathrm{LGM})-\mathrm{AO}(\mathrm{PI}))$. Dotted areas show $95 \%$ significance by Student's $t$ test.

the $\mathrm{AO}(\mathrm{LGM})$, globally averaged surface air temperature is decreased by $4.29 \mathrm{~K}$ compared to the $\mathrm{AO}(\mathrm{PI})$. Thus change of vegetation contributes $0.58 \mathrm{~K}$ of global cooling, which corresponds to $13.5 \%$ amplification of global cooling compared AO results. The global distribution of temperature change in the AOV(LGM) (Fig. 4a) shows a strong cooling over the ice sheets in North America and northern Europe. In other land areas in the Northern Hemisphere, cooling is around $4 \mathrm{~K}$ to $8 \mathrm{~K}$. Precipitation shows general decrease globally between $\mathrm{AOV}(\mathrm{LGM})$ and AOV(PI). Decrease of precipitation is especially larger in tropical Africa, tropical Pacific Ocean and northern mid- and high latitude (Fig. 4c).

We extracted glacial temperature change and precipitation change due to vegetation by multiple subtraction as $(\mathrm{AOV}(\mathrm{LGM})-\mathrm{AOV}(\mathrm{PI}))-(\mathrm{AO}(\mathrm{LGM})-\mathrm{AO}(\mathrm{PI}))$. The result indicates that cooling due to vegetation change is mainly allocated around the middle latitudes of the Northern Hemisphere (Fig. 4b). In Eurasia, more than $30 \%$ (at most $80 \%$ ) of the total cooling at around $45^{\circ} \mathrm{N}$ is due to vegetation change, which is obtained by dividing the contribution of vegetation change to temperature change by total temperature change. In North America, except for the ice sheet, a contribution of vegetation change to the total cooling around $45^{\circ} \mathrm{N}$ exists, however, it is less than $30 \%$. In this area, a change of vegetation from forest to tundra or desert increase the land surface albedo (Fig. 5a) and surface shortwave absorption is reduced (Fig. 6a). This is due to not only vegetation change itself but also snow cover change induced by vegetation change in specific region (Fig. 5b). Surface albedo decreases in northern Siberia in spite of less vegetation change, and is seen to explain albedo change. In this region, precipitation decrease due to vegetation change is sig- nificant (Fig. 4d), hence snow cover and surface albedo decrease. Change of vegetation contributes to the cooling not only over land but also on the ocean (Fig. 4a). Around $45^{\circ} \mathrm{N}$, a southern shift of the sea-ice boundary in winter (Fig. 5c) increases the surface albedo (Fig. 5a) south of Nova Scotia. A slight increase in albedo is seen in the northwestern part of the Pacific Ocean which is related to an increase of sea-ice coverage as well.

In the tropical region, a slight (and non-significant) warming occurs due to vegetation change (Fig. 4b). This is directly from the increase of sensible heat (Fig. 6c), which is caused by a reduction in precipitation (Fig. 4d) and thus evaporation (Fig. 6d). This additional reduction of precipitation shows similar patterns to that of total precipitation change in the LGM mainly (Fig. 4c) so that vegetation change amplifies a decrease of precipitation in the LGM. A significant change induced by vegetation change is seen in the tropical rain belt and the mid- to high latitude continental areas in the Northern Hemisphere (Fig. 4d). The ratio of precipitation change due to vegetation change relative to the precipitation of the $\mathrm{AOV}(\mathrm{PI})$ is most significant in the African Sahel (Fig. 4d).

\subsection{Terrestrial carbon storage during the LGM}

In the present study, we examined three offline LPJ-DGVM experiments in order to obtain the equilibrium carbon storage. $\mathrm{AOV}(\mathrm{LGM}), \mathrm{LGM}(\mathrm{PI})$ and $\mathrm{AO}(\mathrm{LGM})$ were chosen as input for the offline LPJ-DGVM (see Table 1 last column). The sum of four biomass carbon pools and sum of three soil carbon pools as simulated by the offline LPJ-DGVM are shown as "biomass" and "soil carbon", respectively, in Table 3. The results of the offline LPJ-DGVM experiments are driven with the results from the AOV simulation 

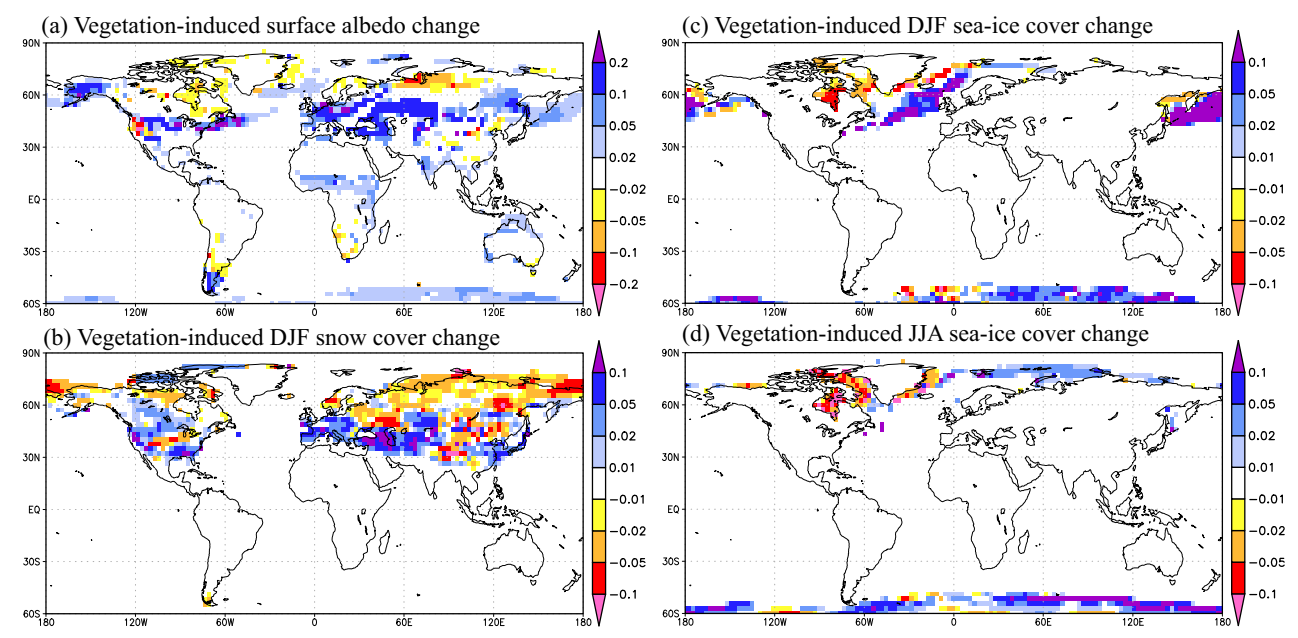

Fig. 5. (a) Annually averaged contribution of vegetation change (which was calculated as (AOV(LGM) - AOV(PI)) - (AO(LGM) - AO(PI)) to surface albedo, (b) same as (a) but December-January-February averaged snow cover fraction, (c) same as (a) but December-JanuaryFebruary averaged sea-ice cover fraction and (d) same as (a) June-July-August averaged sea-ice cover ratio.

to be virtually the same as the actual GCM equilibrium. The AO(LGM) case is used to quantify how lack of the vegetation-atmosphere interaction influences on terrestrial carbon storage.

The AOV(PI) experiment shows 1092 Pg global biomass carbon and 1368 Pg global soil carbon, so that the total global carbon storage is $2450 \mathrm{Pg}$ (Table 3). These values are relatively larger than previous studies which indicate $500-950 \mathrm{Pg}$ global biomass carbon, $850-1700 \mathrm{Pg}$ global soil carbon in the preindustrial (Cramer et al., 2001; Prentice et al., 2011) and $2300 \mathrm{Pg}$ total global carbon in the present-day (Denman et al., 2007; Ciais et al., 2011). The AOV(LGM) experiment shows $828 \mathrm{Pg}$ biomass carbon and $1025 \mathrm{Pg}$ soil carbon, hence the total global carbon storage is $1853 \mathrm{Pg}$ (Table 3). These values are also relatively larger than previous studies which indicate about 1400 Pg total global carbon (Ciais et al., 2011; Prentice et al., 2011). During the LGM, the total terrestrial carbon storage is reduced by $597 \mathrm{Pg}$ compared to that of the preindustrial era. Reduction of $254 \mathrm{PgC}$ out of $597 \mathrm{PgC}$ is due to the change in biomass, and $343 \mathrm{PgC}$ is due to the change in soil carbon. The total reduction of terrestrial carbon during the LGM is equivalent to $282 \mathrm{ppm} \mathrm{CO}_{2}$ emission to the atmosphere (by conversion factor 0.47 (Enting, 1992). This is not so much different from latest value e.g. 0.48 (Zickfeld et al., 2011). On the other hand, by using the AO(LGM) result, the reduction of carbon storage during the LGM is slightly larger than that of the AOV(LGM) result (Table 3). Global biomass and global soil carbon are $823 \mathrm{Pg}$ and 1009 $\mathrm{Pg}$, respectively. Hence reduction of total global carbon storage is $619 \mathrm{Pg}$, which is equivalent to $292 \mathrm{ppm} \mathrm{CO} 2$ emission to the atmosphere.

During the LGM there is no vegetation in the areas covered by the ice sheets. Assuming the flow of the ice sheet completely washes out the soil carbon, there is no carbon storage under or over the ice sheet in the two LGM experiments. We excluded those regions covered by the LGM ice sheet so as to be consistent with this assumption. In the preindustrial experiment our results show that $108 \mathrm{Pg}$ biomass carbon out of $1082 \mathrm{Pg}$, and $280 \mathrm{Pg}$ soil carbon out of $1368 \mathrm{Pg}$, are considered to be "removed" by the LGM ice sheets in North America and Scandinavia. On the other hand, the continental shelf is exposed because of a descent in the sea level, so that terrestrial carbon can be stored there during the LGM. In the AOV(LGM), $157 \mathrm{Pg}$ biomass carbon and $137 \mathrm{Pg}$ soil carbon newly appears on the exposed continental shelf. In the $\mathrm{AO}(\mathrm{LGM})$, these values are $162 \mathrm{PgC}$ and $147 \mathrm{PgC}$, respectively. All the values in the two LGM experiments in Table 3 include both a reduction due to the ice sheet and an increase due to the extended continental shelf. In order to extract the response of the terrestrial carbon pools to the LGM climate, we leave out the areas of the ice sheets and continental shelves and listed their values in parentheses in Table 3. In the AOV(LGM), a 301 Pg reduction of biomass carbon and a $200 \mathrm{Pg}$ reduction of soil carbon occur due to the LGM climate and $\mathrm{CO}_{2}$ level. In the $\mathrm{AO}(\mathrm{LGM})$, reduction of biomass and soil carbon pools are $313 \mathrm{Pg}$ and $227 \mathrm{Pg}$, respectively. Generally, the contribution of the LGM climate and extension of the ice sheet and continental shelf to the total carbon reduction $(597 \mathrm{PgC})$ are reduction of $502 \mathrm{PgC}$, reduction of $388 \mathrm{PgC}$, and increase of $293 \mathrm{PgC}$, respectively, in the $\mathrm{AOV}(\mathrm{LGM})$. In the $\mathrm{AO}(\mathrm{LGM})$, they are reduction of $540 \mathrm{PgC}$, reduction of $388 \mathrm{PgC}$, and increase of $310 \mathrm{PgC}$, for a total decrease of $619 \mathrm{PgC}$.

In areas that do not experience an ice sheet or shelf exposure, the distribution of terrestrial carbon shows substantial changes that reflect the changes in distribution of vegetation. In the AOV(LGM), the largest decrease of biomass occurs in the Siberian forest belt (Fig. 7a). In tropical Africa, there is 

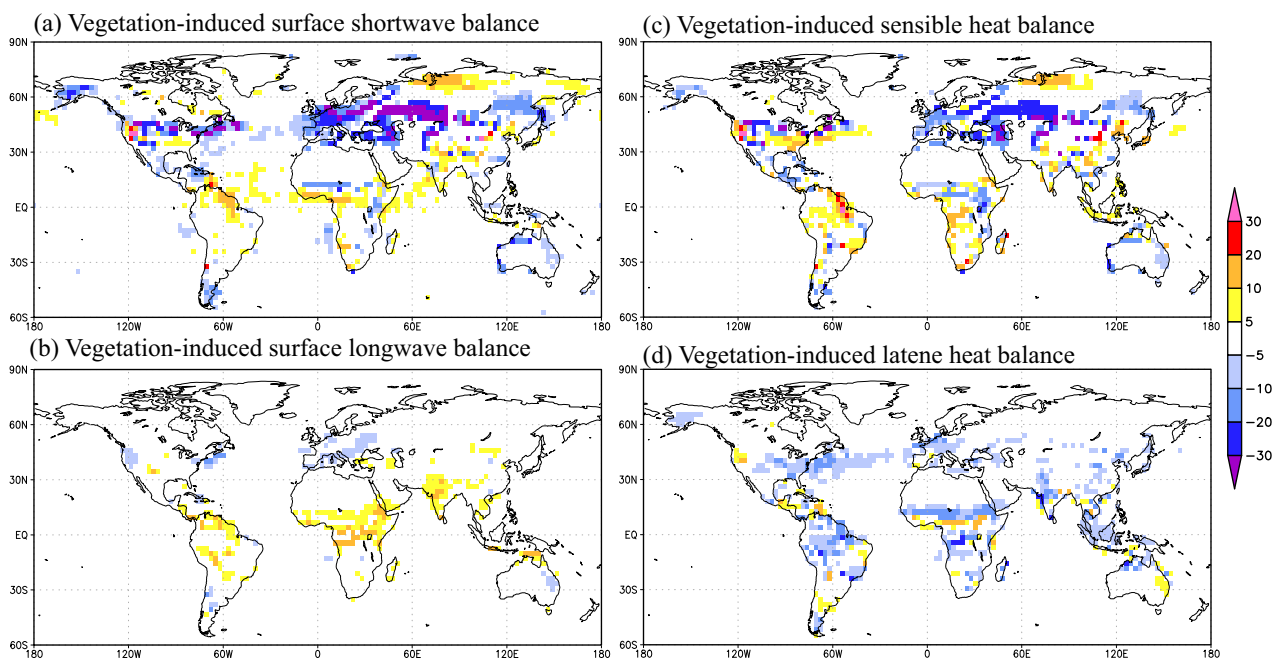

Fig. 6. (a) Annually averaged contribution of vegetation change (which was calculated as (AOV(LGM) - AOV(PI)) - (AO(LGM) - AO(PI)) to surface shortwave balance [ $\mathrm{W} \mathrm{m}^{-2}$ ] (downward positive), (b) same as (a) but surface longwave balance [W $\mathrm{m}^{-2}$ ] (upward positive), (c) same as (a) but surface sensible heat balance $\left[\mathrm{W} \mathrm{m}^{-2}\right]$ (upward positive) and (d) same as (a) but surface latent heat balance [W $\left.\mathrm{m}^{-2}\right]$ (upward positive).

(a) Relative biomass in $\mathbf{A O V}(\mathbf{L G M})$

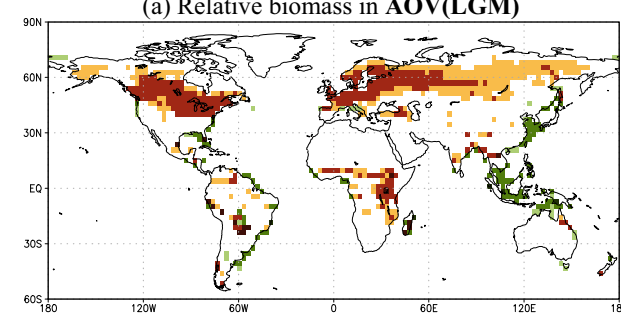

(b) Relative biomass in AO(LGM)

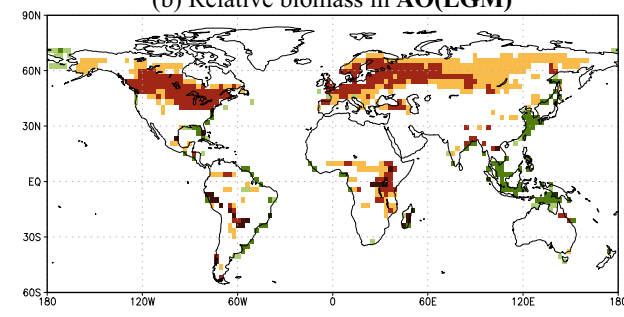

(c) Relative soil carbon in AOV(LGM)

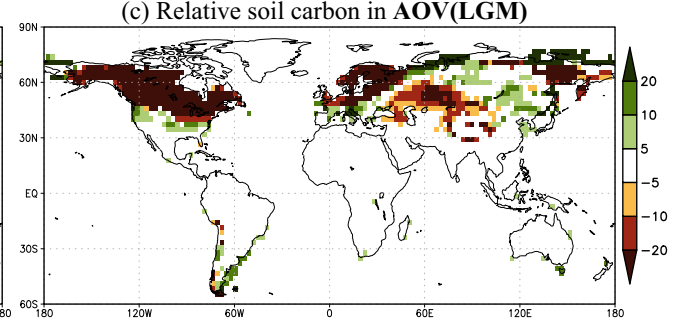

(d) Relative soil carbon in $\mathbf{A O}(\mathbf{L G M})$

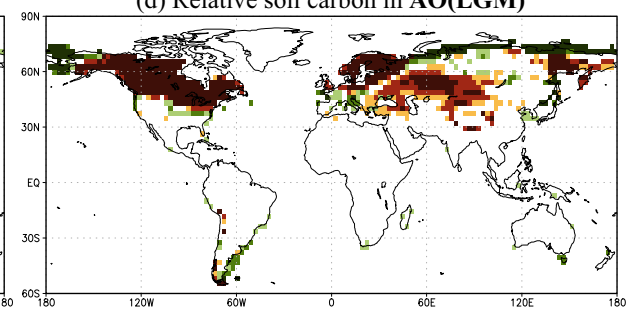

Fig. 7. Equilibrium absolute differences of biomass $\left[\mathrm{kg} \mathrm{m}^{-2}\right]$ in (a) $\mathrm{AOV}(\mathrm{LGM})$ and (b) $\mathrm{AO}(\mathrm{LGM})$ with respect to AOV(PI). Equilibrium absolute differences of soil carbon $\left[\mathrm{kg} \mathrm{m}^{-2}\right]$ in (c) $\mathrm{AOV}(\mathrm{LGM})$ and (d) $\mathrm{AO}(\mathrm{LGM})$ with respect to $\mathrm{AOV}(\mathrm{PI})$. Absolute values are shown in the Appendix Fig. A2.

also a decrease of biomass. Other forest areas also show a decrease in biomass which is consistent with the decrease of NPP (Fig. 3h), but typically less than $5 \mathrm{kgC} \mathrm{m}^{-2}$. The largest decrease of soil carbon is seen in East Siberia and Central Eurasia (Fig. 7c), which corresponds to the replacement of boreal forest by tundra and desert, respectively. This can be explained by the decrease of NPP (Fig. 3h) which also shows the largest decrease in these areas. In these areas, reduction of NPP causes less input to soil carbon pools so that equilibrium soil carbon decreases. Increase of soil carbon is seen in northeast China, northern Siberia and the southern edge of ice sheets in both Europe and North America. This increase of soil carbon is due to lowering of decomposition rate of soil carbon, which corresponds to carbon output from terrestrial ecosystem, due to low temperature in the LGM. Other circumstantial evidence is shown in change of NPP (Fig. 3h), which is regarded as carbon input to terrestrial ecosystem. Change of soil carbon does not show increase in all these regions. In other regions, the soil carbon shows a slight change, less than $\pm 5 \mathrm{kgC} \mathrm{m}^{-2}$.

On the other hand, in the $\mathrm{AO}(\mathrm{LGM})$, distribution of terrestrial carbon storage is generally similar to that of the $\mathrm{AOV}(\mathrm{LGM}$ ) in both vegetation and soil carbon pools (Fig. 7b and d). Differences in these two LGM experiments are seen 
in the edge of the tree line (biomass) and in the wide area of the Northern Hemisphere continent (soil carbon). These differences reflect the changes in habitable zones (biomass) and cooling (soil carbon) due to vegetation-climate feedback.

Offline LPJ-DGVM experiments show biomass response in the LGM (except for new land and preindustrial ice sheet area) to temperature, precipitation and $\mathrm{CO}_{2}$ (almost additive) as well as NPP. On the other hand, soil carbon is not additive (Table 3).

\section{Discussion}

\subsection{Vegetation change and amplification of cooling}

In the present study, our results indicate a cooler and drier climate than is shown in previous studies (Braconnot et al., 2007; Crucifix and Hewitt, 2005; Henrot et al., 2009). Compared to the latest reconstruction (Bartlein et al., 2011), cooling during the LGM is overestimated in both North America and Europe. On the other hand, cooling is underestimated in southern Africa. The pattern of precipitation change is generally the same as the reconstruction in North America and Europe, but the intensity of change is underestimated. Since there is relatively less vegetation in these regions and not a major part of terrestrial carbon storage, the influence of climate difference on biomass and soil carbon is limited. We also obtained similar vegetation changes, such as expansion of tundra, a southward shift of boreal forests, and expansion of desert/arid regions, compared to previous studies (Prentice and Jolly, 2000; Harrison and Prentice, 2003; Crucifix et al., 2005b; Jahn et al., 2005; Henrot et al., 2009; Prentice et al., 2011). The resultant vegetation-climate feedback is positive, which has been shown in previous sensitivity studies (Ganopolski, 2003; Crucifix et al., 2005a; Henrot et al., 2009).

In the present study, the most dominant factor in the vegetation-climate model results is the increase in land surface albedo (Fig. 5a), which is due not only to the replacement of boreal forest by tundra and desert, but also to the increase in snow cover (Fig. 5b) in mid-latitudes, in spite of the reduction in precipitation (Fig. 4d). Generally, the cooling in surface temperature is dominated by reduction of sensible heat from land (Fig. 6c). This sensible heat balance shows a very similar pattern to that of surface shortwave balance (Fig. 6a) which is directly related to surface albedo (Fig. 5a). We obtained $-1.55 \mathrm{~W} \mathrm{~m}^{-2}$ of clear sky surface shortwave forcing which is shown as $-1.4 \mathrm{~W} \mathrm{~m}^{-2}$ by Crucifix and Hewitt (2005). Surface longwave balance (Fig. 6b) and surface latent heat balance (Fig. 6d) do not explain the sensible heat balance (Fig. 6c) induced by vegetation change. In high latitudes, snow cover shows a slight decrease (Fig. 5b), and thus decreases the albedo (Fig. 5a) due to the reduction of precipitation (Fig. 4) which reflects weakening of global water cycle due to cooling induced by vegetation change.
The MIROC-LPJ predicts a boreal forest band in western Siberia that is not seen in previous model studies using GCMs and vegetation models (Harrison and Prentice, 2003; Crucifix et al., 2005b; Prentice et al., 2011). In those studies, the boreal forest on the Eurasian continent is separated into east and west sections, or vanished completely. There are three possible explanations for this overestimation of boreal forest. First, the MIROC-LPJ shows a weaker cooling in western Siberia than do the PMIP2 model results (Braconnot et al., 2007). This weak cooling is not due to the positive vegetation-climate feedback in AOV(LGM) because the offline LPJ-DGVM run, using the result of the $\mathrm{AO}(\mathrm{LGM})$, predicts the same vegetation in this region (not shown). The second reason is related to the lack of fractional coverage representation in the land-surface scheme of the MIROC-LPJ. As described in Sect. 2.3 and O'ishi and Abe-Ouchi (2009), the land-surface scheme of the MIROC is able to handle only one vegetation type in a grid cell, and so it does not handle fractional coverage. We defined the representations of the vegetation types by using combination of individual fractional coverage of PFTs, NPP, LAI, GDD and soil moisture calculated in the coupled LPJ-DGVM. However, there can be an overestimation of a specific vegetation type which is typically the most dominant vegetation type. In AOV(LGM) in the present study, forest coverage in western Siberia was about 0.6 , which was less than that of AOV(PI). However, this forest is assumed to occupy a whole grid cell in the land-surface scheme of the MIROC. Thus this treatment underestimates both the decrease in forest and the cooling due to vegetation feedback. If we could introduce the fractional representation into the land-surface scheme of MIROC, reduction of forest and increase of tundra cause additional cooling in western Siberia as well as in northeastern China and central Eurasia. The third reason is model bias of LPJ-DGVM itself. In AOV(PI), a PFT named "boreal needle-leaved summergreen trees" is overestimated even if we apply a bias correction. This tendency of overestimation may also cause overestimation of this PFT, which is the most dominant in the boreal forest band in AOV(LGM). The improvement of the productivity of boreal needle-leaved summergreen trees in preindustrial or present-day simulations may reduce forest band in the LGM simulation.

\subsection{Carbon storage}

In the present study, the tendency of terrestrial carbon reduction of our results is similar to that of previous studies and falls into the typical range of uncertainty (Prentice et al., 1993; Friedlingstein et al., 1995; François et al., 1998, 1999; Kaplan et al., 2002; Otto et al., 2002; Köhler and Fischer, 2004) when using climate variables that include vegetation feedback. The total 597 Pg reduction of terrestrial carbon falls into the typical range of uncertainty of terrestrial carbon reduction (300 to $700 \mathrm{PgC}$ ). We separated the total reduction of terrestrial carbon into three kinds: response to the LGM 
climate and $\mathrm{CO}_{2}$, washout by ice-sheet coverage, and new stock on the exposed continental shelf.

Response of terrestrial biosphere to the cool, dry, and low$\mathrm{CO}_{2}$ LGM environment is seen in the reasonable reduction of the NPP (Fig. 3h), biomass (Fig. 7a) and vegetation coverage (Fig. 1c and d), as well as in previous studies. The contribution of temperature, precipitation and $\mathrm{CO}_{2}$ level in the LGM to reduction of global total biomass is almost additive (see $T, C$ and $P$ in Table 3 ) as same as that of NPP. On the other hand, summing contributions of these factors to global total soil carbon does not explain the global total soil carbon reduction in AOV(LGM). Since the response of biomass is additive, the response of total dead biomass as input to soil carbon is also considered to be additive. A possible explanation is non-linear relation of temperature and decomposition speed and soil carbon (Lloyd and Taylor, 1994) and nonlinear dependency of decomposition speed and soil carbon to soil moisture which is related to temperature and precipitation (Foley, 1995) in LPJ-DGVM.

During the LGM, the assumption of washout by the ice sheet may overestimate the reduction of terrestrial carbon, because the carbon flux and storage in the present-day that are predicted by the LPJ-DGVM tend to be larger than the typical values (Sitch et al., 2003; Denman et al., 2007) and those among multi-models (Cramer et al., 2001). The second reason is we do not know how much carbon was stored below an ice sheet during the LGM. We assumed all carbon is removed by the ice sheet, which has also been assumed in previous studies. In this case, carbon washout depends on how much carbon was stored in the preindustrial control experiment. On the contrary, the Glacial Burial Hypothesis (Zeng, 2003, 2007) suggests that $500 \mathrm{PgC}$ was buried under the LGM ice sheets. This value is comparable to a decrease of $383 \mathrm{PgC}$, which we assumed to have been removed by the ice sheets. However, $\delta^{13} \mathrm{C}$ reconstruction indicates that $\mathrm{CO}_{2}$ rise during the last deglaciation is not from land but from ocean (Lourantou et al., 2010), which is consistent to our assumption of washout.

Since we use a sea level change of $-150 \mathrm{~m}$, which is the largest estimation (Yokoyama et al., 2000), the exposed ice-free continental shelf was maximized. In our model setting, the total area of exposed ice-free continental shelf is $23 \times 10^{12} \mathrm{~m}^{2}$, which is two times larger than that of previous studies (Zeng, 2003; Montenegro et al., 2006). If we assume a more moderate sea level change, such as that noted in Montenegro et al. (2006), the increase of terrestrial carbon $(293 \mathrm{PgC})$ is reduced by about half (which is roughly estimated proportionally to the area of ice-free continental shelf) and falls into the range of previous studies (112-323 PgC).

The impact of using the AOGCM results instead of the AOVGCM results is far smaller than the total amount of vegetation, soil, and total carbon storage during the LGM (less than $\pm 20 \mathrm{PgC}$ out of several $1000 \mathrm{PgC}$; see Table 3 ) and does not change the main result in the present study. However, these differences are non-negligible if we try to explain the
$100 \mathrm{ppm}$ difference of atmospheric $\mathrm{CO}_{2}$ concentration between the LGM and the preindustrial era, which corresponds to $200 \mathrm{PgC}$.

\section{Conclusions}

In the present study we apply a coupled atmosphere-oceanvegetation GCM for predicting the LGM climate and vegetation in order to quantify how the vegetation-climate feedback affected the LGM climate. Our sensitivity experiments show tendencies similar to previous paleodata and paleomodeling studies for changes in vegetation and climate. In the present study, vegetation changes during the LGM amplify cooling during the LGM by $13.5 \%$, which is mostly caused by increases of the land surface albedo. We separate the LGM environment changes into three factors: temperature, precipitation, and $\mathrm{CO}_{2}$. We then investigate the impact of each of these on the vegetation distribution during the LGM. Offline sensitivity experiments indicate that temperature and precipitation are dominant in the vegetation distribution during the LGM. Low levels of $\mathrm{CO}_{2}$ during the LGM affects only the tropical regions.

We also investigate terrestrial carbon storage during the LGM by offline dynamical vegetation model experiments. Temperature, precipitation (predicted by GCM experiment) and atmospheric $\mathrm{CO}_{2}$ levels of GCM experiments are used as forcing. The results show that terrestrial carbon storage is generally the same, both in pattern and quantity, regardless of whether we include vegetation-climate feedback in the input variables. However, the difference is comparable to carbon quantity, which corresponds to the $100 \mathrm{ppm}$ of $\mathrm{CO}_{2}$ difference between the LGM and the preindustrial era. We determine that inclusion of vegetation-climate feedback should be taken into account if we wish to explain the lowering of atmospheric $\mathrm{CO}_{2}$ during the LGM.

We separate the terrestrial carbon difference between the LGM and preindustrial era into three factors: response to the LGM climate and $\mathrm{CO}_{2}$, washout by ice-sheet coverage, and new stock on the exposed continental shelf during the LGM. In the present study, the total $597 \mathrm{Pg}$ of reduction of terrestrial carbon is explained by a decrease by $502 \mathrm{Pg}$ due to response to the LGM environment, a decrease by 388 Pg removed by the ice sheet, and an increase by $293 \mathrm{Pg}$ due to new storage on the exposed continental shelf. The decrease of carbon storage due to the LGM environment is consistent with the previous model and data studies. Washout by the ice sheets depends on how much carbon is stored in these regions in the preindustrial condition. Our results show similar values to those previous studies, regardless of the assumption that carbon is washed out of or stored under the ice. Carbon storage on the exposed continental shelf is larger than that of previous studies because we adopt the largest possible sea level change, as shown by paleo-reconstructions. Carbon storage on the exposed continental shelf falls into the range 
of variability among previous studies if we assumed the same area as did previous studies.

Our result in the present study is done by just one model. Since our model tends to overestimate terrestrial carbon storage compared to previous studies (Cramer et al., 2001; Denman et al., 2007; Ciais et al., 2011; Prentice et al., 2011), reduction of terrestrial carbon in the LGM climate is considerably larger in range of uncertainty (Bird et al., 1994). We also assumed the largest extent of the continental shelf so that the new storage on the continental shelf is maximized. Our model is considered to overestimate response (both positive and negative) of carbon storage in the LGM than previous model studies. Our result indicates that total terrestrial carbon response in the LGM is calculated by various factors of terrestrial carbon change (ice sheet washout, new storage on continental shelf, response of photosynthesis and vegetation feedback to LGM climate). It is not yet clear where the $200 \mathrm{PgC}$ is stored; it corresponds to a decrease of $100 \mathrm{ppm}$ of atmospheric $\mathrm{CO}_{2}$ during the LGM (Lourantou et al., 2010; Ciais et al., 2011; Shakun et al., 2012). When we try to determine the global allocation of carbon in the earth system (atmosphere, ocean and land) during the LGM, we find that not only the uncertainty of photosynthesis response but also vegetation-climate feedback and the uncertainty of sea level change should be taken into account. This is a common important problem among other models as well as our model.

\section{Appendix A}

(a) Vegetation index in $\mathbf{A O V}(\mathbf{P I})$ w/o bias correction

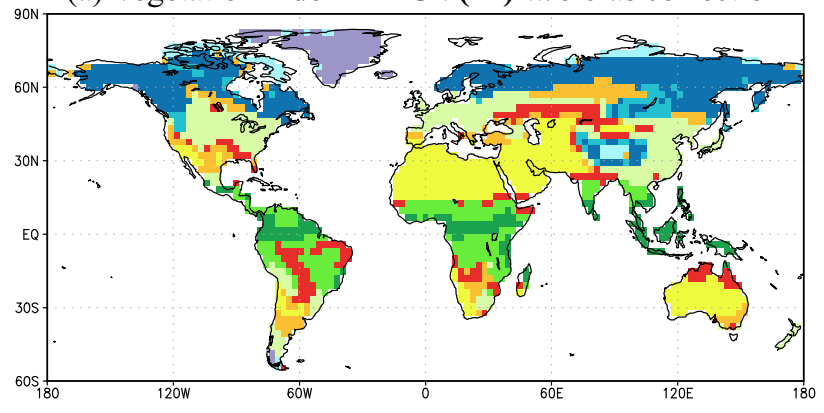

(b) Vegetation index in $\mathbf{A O V}(\mathbf{L G M})$ w/o bias correction

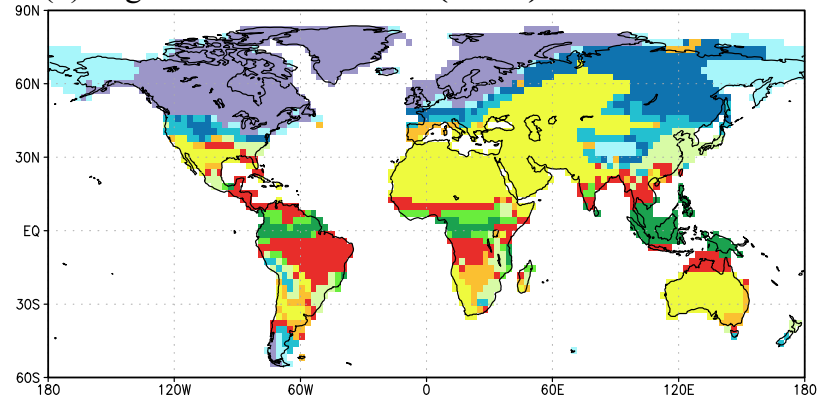

Fig. A1. The same as Fig. 1 but without bias correction (a) $\mathrm{AOV}(\mathrm{PI})$ and (b) AOV(LGM).

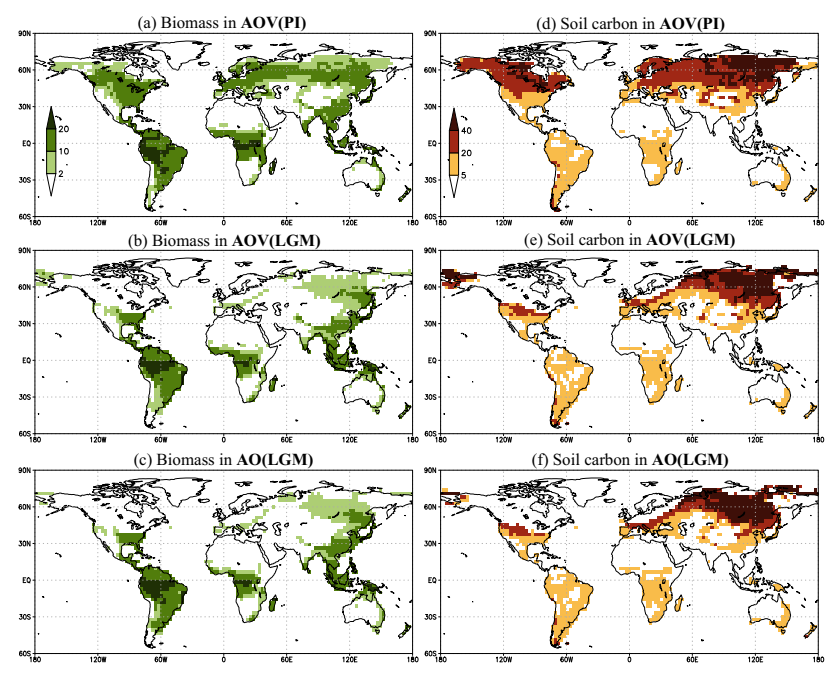

Fig. A2. The same as Fig. 7 but absolute biomass $\left[\mathrm{kg} \mathrm{m}^{-2}\right]$ in (a) $\mathrm{AOV}(\mathrm{PI})$, (b) AOV(LGM) and (c) AO(LGM) and soil carbon $\left[\mathrm{kg} \mathrm{m}^{-2}\right]$ in (d) AOV(PI), (d) AOV(LGM) and AO(LGM).

Acknowledgements. This research is supported by the GRENE Arctic climate Change Research Project.

Edited by: M. Crucifix

\section{References}

Abe-Ouchi, A., Segawa, T., and Saito, F.: Climatic Conditions for modelling the Northern Hemisphere ice sheets throughout the ice age cycle, Clim. Past, 3, 423-438, doi:10.5194/cp-3-423-2007, 2007.

Bartlein, P. J., Harrison, S. P., Brewer, S., Connor, S., Davis, B. A. S., Gajewski, K., Guiot, J., Harrison-Prentice, T. I., Henderson, A., O., Peyron, A. H., Prentice, I. C., Scholze, M., Seppa, H., Shuman, B., Sugita, S., Thompson, R. S., Viau, A. E., Williams, J., and $\mathrm{Wu}, \mathrm{H}$.: Pollen-based continental climate reconstructions at 6 and $21 \mathrm{ka}$ : a global synthesis, Clim. Dynam., 37, 775-802, 2011.

Bird, M. I., Lloyd, J. L., and Farquhar, G. D.: Terrestrial carbon storage at the LGM, Nature, 371, 566-566, 1994.

Braconnot, P., Otto-Bliesner, B., Harrison, S., Joussaume, S., Peterchmitt, J.-Y., Abe-Ouchi, A., Crucifix, M., Driesschaert, E., Fichefet, Th., Hewitt, C. D., Kageyama, M., Kitoh, A., Laîné, A., Loutre, M.-F., Marti, O., Merkel, U., Ramstein, G., Valdes, P., Weber, S. L., Yu, Y., and Zhao, Y.: Results of PMIP2 coupled simulations of the Mid-Holocene and Last Glacial Maximum Part 1: experiments and large-scale features, Clim. Past, 3, 261277, doi:10.5194/cp-3-261-2007, 2007.

Ciais, P., Tagliabue, A., Cuntz, M., Bopp, L., Scholze, M., Hoffmann, G., Lourantou, A., Harrison, S. P., Prentice, I. C., Kelley, D. I., Koven, C., and Piao, S. L.: Large inert carbon pool in the terrestrial biosphere during the Last Glacial Maximum, Nat. Geosci., 5, 74-79, 2011. 
CLIMAP Project Members: The Surface of the Ice-Age Earth, Science, 191, 1131-1137, 1976.

CLIMAP Project Members: The Last Interglasial Ocean, Quarternary Res., 21, 123-224, 1984.

Cramer, W., Bondeau, A., Woodward, F. I., Prentice, I. C., Betts, R. A., Brovkin, V., Cox, P. M., Fisher, V., Foley, J. A., Friend, A. D., Kucharik, C., Lomas, M. R., Ramankutty, N., Sitch, S., Smith, B., White, A., and Young-Molling, C.: Global response of terrestrial ecosystem structure and function to $\mathrm{CO}_{2}$ and climate change: results from six dynamic global vegetation models, Global Change Biol., 7, 357-373, 2001.

Crucifix, M. and Hewitt, C. D.: Impact of vegetation changes on the dynamics of the atmosphere at the Last Glacial Maximum, Clim. Dynam., 25, 447-459, 2005.

Crucifix, M., Betts, R. A., and Cox, P. M.: Vegetation and climate variability: a GCM modelling study, Clim. Dynam., 24, 457-467, 2005a.

Crucifix, M., Betts, R. A., and Hewitt, C. D.: Pre-industrialpotential and Last Glacial Maximum global vegetation simulated with a coupled climate-bio sphere model: Diagnosis of bioclimatic relationships, Global Planet. Change, 45, 295-312, $2005 \mathrm{~b}$.

Denman, K. L., Brasseur, G., Chidthaisong, A., Ciais, P., Cox, P. M., Dickinson, R. E., Hauglustaine, D., Heinze, C., Holland, E., Jacob, D., Lohmann, U., Ramachandran, S., daSilbaDias, P. L., Wofsy, S. C., and Zhang, X.: Coupling Between Changes in the Climate System and Biogeochemistry. In: Climate Change 2007 The Physical Science Basis: Contribution of working Groupe I to the Fourth Assesment Report of the Intergovernmental Panel on Climate Change, edited by: Solomon, S., Qin, D., Manning, M., Chen, Z., Marquis, M., Averyt, K. B., Tignor, M., and Miller, H. L., Cambridge University Press, Cambridge, 2007.

Ehret, U., Zehe, E., Wulfmeyer, V., Warrach-Sagi, K., and Liebert, J.: HESS Opinions "Should we apply bias correction to global and regional climate model data?", Hydrol. Earth Syst. Sci., 16, 3391-3404, doi:10.5194/hess-16-3391-2012, 2012.

Enting, I. G.: The incompatibility of ice-core $\mathrm{CO}_{2}$ data with reconstruction of biotic $\mathrm{CO}_{2}$ sources (II) - the influence of $\mathrm{CO}_{2}$ fertilized growth, Tellus B, 44, 23-32, 1992.

Faloon, P. D., Jones, C. D., Ades, M., and Paul, K.: Direct soil moisture controls of future global soil carbon changes; an important source of uncertainty, Global Biogeochem. Cy., 25, GB3010, doi:10.1029/2010BG003938, 2011.

Falloon, P. D., Dankers, R., Betts, R. A., Jones, C. D., Booth, B. B. B., and Lambert, F. H.: Role of vegetation change in future climate under the A1B scenario and a climate stabilisation scenario, using the HadCM3C Earth system model, Biogeosciences, 9, 4739-4756, doi:10.5194/bg-9-4739-2012, 2012.

Faure, H., Adams, J., Debenay, J., Faure-Denard, L., Grants, D., Pirazzoli, P., Thomassin, B., Velichko, A., and Zazo, C.: Carbon storage and continental land surface change since the Last Glacial Maximum, Quarternary Sci. Rev., 15, 843-849, 1996.

Foley, J. A.: An equilibrium-model of the terrestrial carbon budget, Tellus B, 47, 310-319, 1995.

François, L. M., Delier, C., Warnant, P., and Munhoven, G.: Modelling the glacial-interglacial changes in the continental biosphere, Global Planet. Change, 17, 37-52, 1998.

François, L. M., Godderis, Y., Warnant, P., Ramstein, G., de Noble, N., and Lorenz, N.: Carbon stocks and isotopic budgets of the terrestrial biosphere at mid-Holocene and last glacial maximum times, Chem. Geol., 159, 163-189, 1999.

Friedlingstein, P., Prentice, K. C., Fung, I. Y., John, J. G., and Brasseur, G. P.: Carbon-biosphere-climate interactions in the last glacial maximum climate, J. Geophys. Res., 100, 7203-7221, 1995.

Ganopolski, A.: Glacial integrative modelling, Philos. T. Roy. Soc., 361, 1871-1884, doi:10.1098/rsta.2003.1246, 2003.

Gerber, S., Joos, F., and Prentice, I. C.: Sensitivity of a dynamic global vegetation model to climate and atmospheric $\mathrm{CO}_{2}$, Glob. Change Biol., 10, 1223-1239, 2004.

Hagemann, S., Chan, C., Hearter, J. O., Heinke, J., Gerten, D., and Piani, C.: Impact of a Statistical Bias Correction on the Projected Hydrological Changes Obtained from Three GCMs and Two Hydrology Models, J. Hydrometeorol., 12, 556-578, doi:10.1175/2011JHM1336.1, 2011.

Harrison, S. P. and Prentice, I. C.: Climate and $\mathrm{CO}_{2}$ controls on global vegetation distribution at the last glacial maximum: analysis based on palaeovegetation data, biome modelling and palaeoclimate simulations, Glob. Change Biol., 9, 983-1004, 2003.

Hasumi, H.: CCSR Ocean Component Model (COCO), version 4.0, center for Climate System Research Report 25, 103 pp., available at: http://www.ccsr.u-tokyo.ac.jp/ hasumi/ COCO/coco4.pdf, 2006.

Hasumi, H. and Emori, S.: K-1 Coupled GCM (MIROC) Description, k-1 Technical Report No. 1, Center for Climate System Research (CCSR, Univ. of Tokyo), National Institute for Environmental Studies (NIES), Frontier Research Center for Global Change (FRCGC), 2004

Henrot, A.-J., François, L., Brewer, S., and Munhoven, G.: Impacts of land surface properties and atmospheric $\mathrm{CO}_{2}$ on the Last Glacial Maximum climate: a factor separation analysis, Clim. Past, 5, 183-202, doi:10.5194/cp-5-183-2009, 2009.

Jahn, A., Claussen, M., Ganopolski, A., and Brovkin, V.: Quantifying the effect of vegetation dynamics on the climate of the Last Glacial Maximum, Clim. Past, 1, 1-7, doi:10.5194/cp-1-1-2005, 2005.

Jones, C., McConnell, C., Coleman, K., Cox, P., Faloon, P., Jenkinson, D., and Powlson, D.: Global climate change and soil carbon stocks; predictions from two contrasting modelsfor the turnover of organic carbon in soil, Glob. Change Biol., 11, 154-166, doi:10.1111/j.1365-2486.2004.00885.x, 2004.

Joos, F., Gerber, S., Prentice, I. C., Otto-Bliesner, B. L., and Valdes, P. J.: Transient simulations of Holocene atmospheric carbon dioxide and terrestrial carbon since the Last Glacial Maximum, Global Biogeochem. Cy., 18, GB2002, doi:10.1029/2003GB002156, 2004.

Joussaume, S. and Taylor, K. E.: The Paleoclimate Modeling Intercomparison Project, WCRP 111: Proceedings of the third PMIP Workshop, 2000.

Jouzel, J., Barkov, N. I., Barnola, J. M., Bender, M., Chappellaz, J., Genthon, C., Kotlyakov, V. M., Lipenkov, V., Lorius, C., Petit, J. R., Raynaud, D., Raisbeck, G., Ritz, C., Sowers, T., Stievenard, M., Yiou, F., and Yiou, P.: Extending the Vostok ice-core record of palaeoclimate to the penultimate glacial period, Nature, 364, 407-412, 1993.

Kaplan, J. O., Prentice, I. C., Knorr, W., and Valdes, P. J.: Modeling the dynamics of terrestrial carbon storage since the Last Glacial Maximum, Geophys. Res. Lett., 29, 2074, doi:10.1029/2002GL015230, 2002. 
Kohfeld, K. and Harrison, S.: How well can we simulate past climates? Evaluating the models using global palaeoenvironmental datasets, Quaternary Sci. Rev., 19, 321-346, 2000.

Köhler, P. and Fischer, H.: Simulating changes in the terrestrial biosphere during the last glacial/interglacial transition, Global Planet. Change, 43, 33-55, 2004.

Köhler, P., Joos, F., Gerber, S., and Knutti, P.: Simulated changes in vegetation distribution, land carbon storage, and atmospheric $\mathrm{CO}_{2}$ in response to a collapse of the North Atlantic thermohaline circulation, Clim. Dynam., 25, 689-708, 2005.

Kucera, M., Rosell-Melé, A., Schneider, R., Waelbroeck, C., and Weinelt, M.: Multiproxy approach for the reconstruction of the glacial ocean surface (MARGO), Quaternary Sci. Rev., 25, 813819, 2005.

Lloyd, J. and Taylor, J. A.: On the temperature-dependent of soil respiration, Funct. Ecol., 8, 315-323, 1994.

Lourantou, A., Lavrič, J. V., Köhler, P., Barnola, J., Paillard, D., Michel, E., Raynaud, D., and Chappellaz, J.: Constrain of the $\mathrm{CO}_{2}$ rise by new atmospheric carbon isotopic measurements during the last deglaciation, Global Biogeochem. Cy., 24, GB2015, doi:10.1029/2009GB003545, 2010.

Mahowald, N. M., Muhs, D. R., Levis, S., Rasch, P. J., Yoshioka, M., Zender, C. S., and Luo, C.: Change in atmospheric mineral aerosols in response to climate: Last glacial period, preindustrial, modern, and doubled carbon dioxide climates, J. Geophys. Res., 111, D10202, doi:10.1029/2005JD006653, 2006.

Meehl, G. A., Stocker, T. F., Collins, W. D., Friedlingstein, P., Gaye, A. T., Gregory, J. M., Kitoh, A., Knutti, R., Murphy, J. M., Noda, A., Raper, S. C. B., Watterson, I. G., Weaver, A. J., and Zhao, Z.-C.: Global Climate Projection, in: Climate Change 2007 The Physical Science Basis: Contribution of working Groupe I to the Fourth Assesment Report of the Intergovernmental Panel on Climate Change, edited by: Solomon, S., Qin, D., Manning, M., Chen, Z., Marquis, M., Averyt, K. B., Tignor, M., and Miller, H. L., Cambridge university press, Cambridge, 2007.

Monnin, E., Indermühle, A., Dällenbach, A., Flückiger, J., Stauffer, B., Stocker, T. F., Raynaud, D., and Barnola, J.-M.: Atmospheric $\mathrm{CO}_{2}$ Concentrations over the Last Glacial Termination, Science, 291, 112-114, 2001.

Montenegro, A., Eby, M., Kaplan, J. O., Meissner, K. J., and Weaver, A. J.: Carbon storage on exposed continental shelves during the glacial-interglacial transition, Geophys. Res. Lett., 33, L08703, doi:10.1029/2005GL025480, 2006.

O'ishi, R. and Abe-Ouchi, A.: Influence of dynamic vegetation on climate change arising from increasing $\mathrm{CO}_{2}$, Clim. Dynam., 33, 645-663, 2009.

O'ishi, R. and Abe-Ouchi, A.: Polar amplification in the mid-Holocene derived from dynamical vegetation change with a GCM, Geophys. Res. Lett., 38, L14702, doi:10.1029/2011GL048001, 2011.

Otto, D., Rasse, D., Kaplan, J. O., Warnant, P., and François, L.: Biospheric carbon stocks reconstructed at the Last Glacial Maximum: comparison between general circulation models using prescribed and computed sea surface temperatures, Global Planet. Change, 33, 117-138, 2002.

Peltier, W. R.: Ice Age Paleotopography, Science, 265, 195-201, 1994.

Peltier, W. R.: Global glacial isostasy and the surface of the iceage earth: The ice-5G (VM2) model and grace, Annu. Rev. Earth
Planet. Sc., 32, 111-149, 2004.

Prentice, I. C. and Harrison, S. P.: Ecosystem effects of $\mathrm{CO}_{2}$ concentration: evidence from past climates, Clim. Past, 5, 297-307, doi:10.5194/cp-5-297-2009, 2009.

Prentice, I. C. and Jolly, D.: Mid-Holocene and glacial-maximum vegetation geography of the northern continents and Africa, J. Biogeogr., 27, 507-519, 2000.

Prentice, I. C. and Webb, T.: BIOME 6000: reconstructing global mid-Holocene vegetation patterns from palaeoecological records, J. Biogeogr., 25, 997-1005, 1998.

Prentice, I. C., Sykes, M. T., Lautenschlager, M., Harrison, S. P., Denissenko, O., and Bartlein, P. J.: Modelling global vegetation patterns and terrestrial carbon storage at the last glacialmaximum, Global Ecol. Biogeogr. Lett., 3, 67-76, 1993.

Prentice, I. C., Harrison, S. P., and Bertlein, P. J.: Global vegetation and terrestrial carbon cycle changes after the last ice age, New Phytol., 189, 988-998, 2011.

Shakun, J. D., Clark, P. U., He, F., Marcott, S. A., Mix, A. C., Liu, Z., Otto-Bliesner, B., Schmittner, A., and Bard, E.: Global warming preceded by increasing carbon dioxide concentrations during the last deglaciation, Nature, 484, 49-54, 2012.

Sitch, S., Smith, B., Prentice, I. C., Arneth, A., Bondeau, A., Cramer, W., Kaplan, J. O., Levis, S., Lucht, W., Sykes, M. T., Thonicke, K., and Venevsky, S.: Evaluation of ecosystem dynamics, plant geography and terrestrial carbon cycling in the LPJ dynamic global vegetation model, Glob. Change Biol., 9, 161-185, 2003.

Takata, K., Emori, S., and Watanabe, T.: Development of the minimal advanced treatments of surface interaction and runoff, Global Planet. Change, 38, 209-222, 2003.

Takemura, T., Egashira, M., Matsuzawa, K., Ichijo, H., O’ishi, R., and Abe-Ouchi, A.: A simulation of the global distribution and radiative forcing of soil dust aerosols at the Last Glacial Maximum, Atmos. Chem. Phys., 9, 3061-3073, doi:10.5194/acp-93061-2009, 2009.

Uppala, S. M., KÅllberg, P. W., Simmons, A. J., Andrae, U, Bechtold, V. da Costa, Fiorino, M., Gibson, J. K., Haseler, J., Hernandez, A., Kelly, G. A., Li, X., Onogi, K., Saarinen, S., Sokka, N., Allan, R. P., Andersson, E., Arpe, K., Balmaseda, M. A., Beljaars, A. C. M., van de Berg, L., Bidlot, J., Bormann, N., Caires, S., Chevallier, F., Dethof, A., Dragosavac, M., Fisher, M., Fuentes, M., Hagemann, S., Ho'lm, E., Hoskins, B. J., Isaksen, L., Janssen, P. A. E. M., Jenne, R., McNally, A. P., Mahfouf, J. F., Morcrette, J. J., Rayner, N. A., Saunders, R. W., Simon, P., Sterl, A., Trenberth, K. E., Untch, A., Vasiljevic, D., Viterbo, P., and Woollen, J.: The ERA-40 re-analysis, Q. J. Roy. Meteorol. Soc., 131, 2961-3012, doi:10.1256/qj.04.176, 2005.

Waelbroeck, C., Paul, A., Kucera, M., Rosell-Melé, A., Weilt, M., Schneider, R., Mix, A., Abelmann, A., Armand, L., Bard, E., Barker, S., Barrows, T., Benway, H., Cacho, I., Chen, M., Cortijo, E., Crosta, X., de Vernal, A., Dokken, T., Duprat, J., Elderfield, H., Eynaud, F., Gersonde, R., Hayes, A., Henry, M., HillaireMarcel, C., Huang, C., Jansen, E., Juggins, S., Kallel, N., Kiefer, T., Kienast, M., Labeyrie, L., Leclaire, H., Londeix, L., Mangin, S., Matthiessen, J., Marret, F., Meland, M., Morey, A., Mulitza, S., Pflaumann, U., Pisias, N., Radi, T., Rochon, A., Rohling, E., Sbaffi, L., Schäfer-Neth, C., Solignac, S., Spero, H., Tachikawa, K., and Turon, J.: Constraints on the magnitude and patterns of ocean cooling at the Last Glacial Maximum, Nat. Geosci., 2, 
127-132, doi:10.1038/NGEO411, 2009.

Wyputta, U. and McAvaney, B. J.: Influence of vegetation changes during the Last Glacial Maximum using the BMRC atmospheric general circulation model, Clim. Dynam., 17, 923-932, 2001.

Xie, P. and Arkin, P. A.: A 17-year monthly analysis based on gauge observations, satellite estimates, and numerical model outputs, B. Am. Meteorol. Soc., 78, 2539-2558, 1997.

Yokoyama, Y., Lambeck, K., DeDeckker, P., Johnston, P., and Fifield, L. K.: Timing of the Last Glacial Maximum from observed sea-levelminima, Nature, 406, 713-716, 2000.

Yu, G., Chen, X., Ni, J., Cheddadi, R., Guiot, J., Han, H., Harrison, S. P., Huang, C., Ke, M., Kong, Z., Li, S., Li, W., Liew, P., Liu, G., Liu, J., Liu, Q., Liu, K.-B., Prentice, I. C., Qui, W., Ren, G., Song, C., Sugita, S., Sun, X., Tang, L., Campo, E. V., Xia, Y., Xu, Q., Yan, S., Yang, X., Zhao, J., and Zheng, Z.: Palaeovegetation of China: a pollen data-based synthesis for the mid-Holocene and last glacial maximum, J. Biogeogr., 27, 635-664, 2000.
Zeng, N.: Glacial-Interglacial Atmospheric $\mathrm{CO}_{2}$ Change - The Glacial Burial Hypothesis, Adv. Atmos. Sci., 20, 677-693, 2003.

Zeng, N.: Quasi-100 ky glacial-interglacial cycles triggered by subglacial burial carbon release, Clim. Past, 3, 135-153, doi:10.5194/cp-3-135-2007, 2007.

Zickfeld, K., Eby, M., Matthews, H. D., and Schmitner, A.: Nonlinearity of Carbon Cycle Feedbacks, J. Climate, 24, 4255-4275, doi:10.1175/2011JCLI3898.1, 2011. 